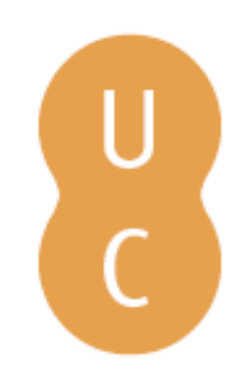

\title{
pompalina
}

\section{Comacchio: leitura de um território}

Autor(es): $\quad$ Farinella, Romeo, ed. lit.; Previati, Lucilla; Ronconi, Michele; Dorato, Elena; Clementi, Alice; Luciani, Anna; Soltysiuk, Justina

Publicado por: Imprensa da Universidade de Coimbra

URL

persistente:

URI:http://hdl.handle.net/10316.2/39322

DOI:

DOI:http://dx.doi.org/10.14195/978-989-26-1025-2_7

Accessed : $\quad$ 26-Apr-2023 12:52:49

A navegação consulta e descarregamento dos títulos inseridos nas Bibliotecas Digitais UC Digitalis, UC Pombalina e UC Impactum, pressupõem a aceitação plena e sem reservas dos Termos e Condições de Uso destas Bibliotecas Digitais, disponíveis em https://digitalis.uc.pt/pt-pt/termos.

Conforme exposto nos referidos Termos e Condições de Uso, o descarregamento de títulos de acesso restrito requer uma licença válida de autorização devendo o utilizador aceder ao(s) documento(s) a partir de um endereço de IP da instituição detentora da supramencionada licença.

Ao utilizador é apenas permitido o descarregamento para uso pessoal, pelo que o emprego do(s) título(s) descarregado(s) para outro fim, designadamente comercial, carece de autorização do respetivo autor ou editor da obra.

Na medida em que todas as obras da UC Digitalis se encontram protegidas pelo Código do Direito de Autor e Direitos Conexos e demais legislação aplicável, toda a cópia, parcial ou total, deste documento, nos casos em que é legalmente admitida, deverá conter ou fazer-se acompanhar por este aviso.

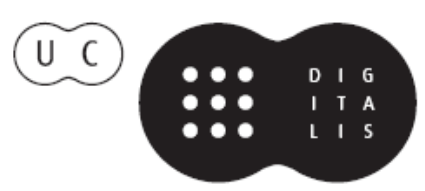




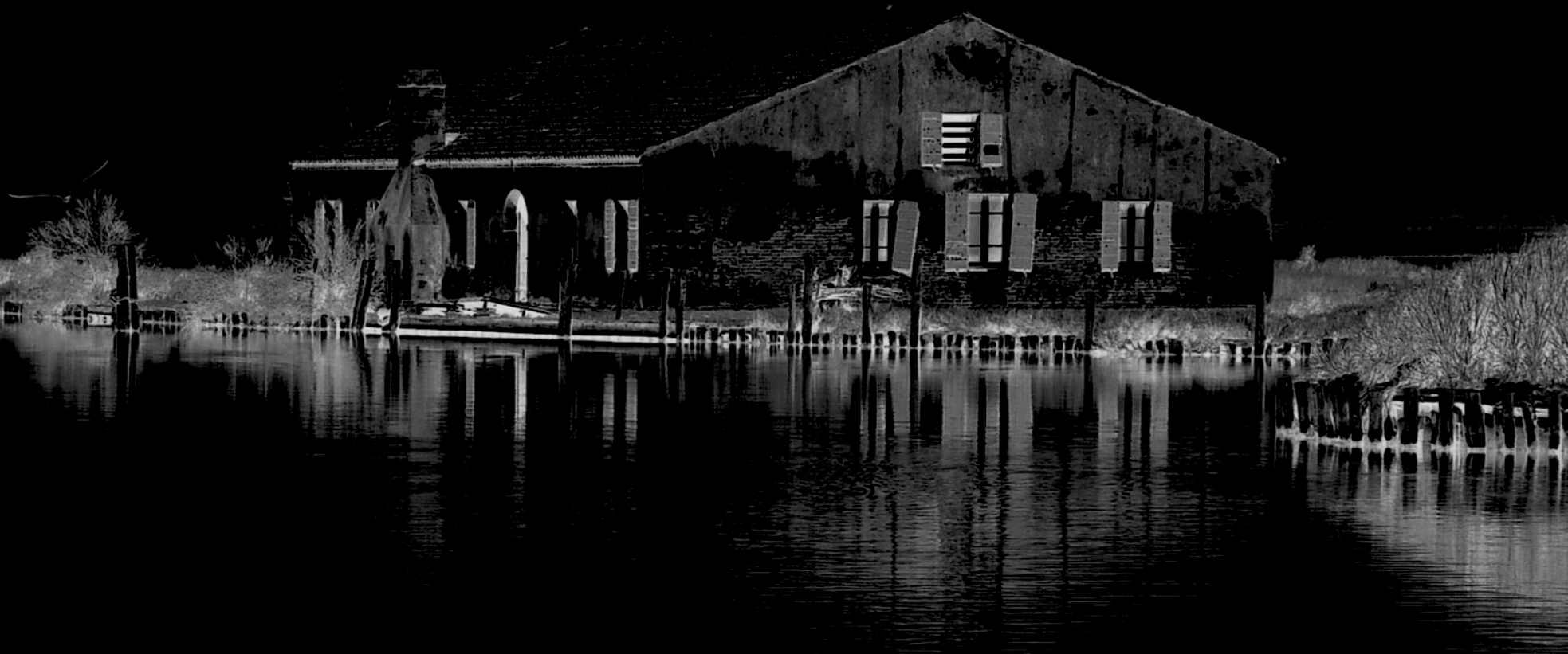

\section{COMACCHIO}

\section{LEITURA DE UM TERRITÓRIO}

ROMEO FARINELLA (Coordenador)

LUCILLA PREVIATI MICHELE RONCONI ELENA DORATO ALICE CLEMENTI ANNA LUCIANI JUSTINA SOLTYSIUK 


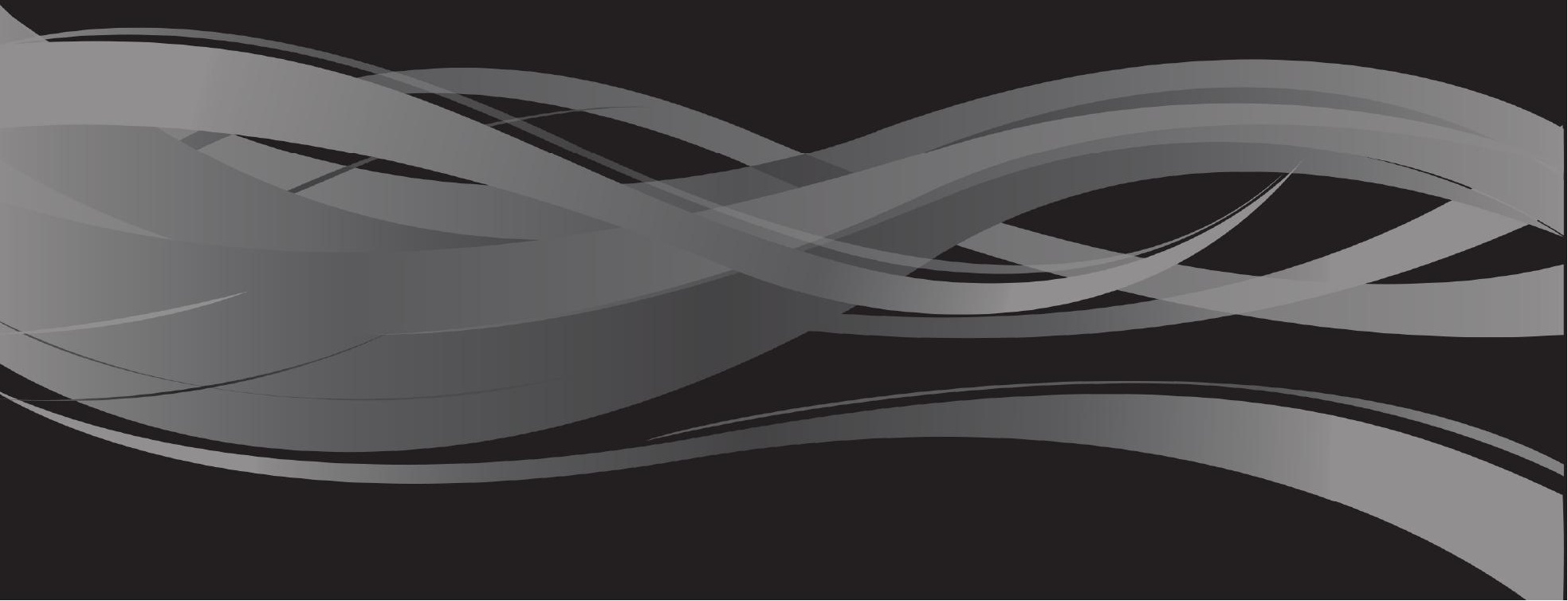




\section{A CONSTRUÇÃO DE UM TERRITÓRIO}

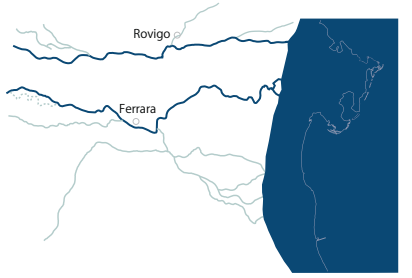

Idade do Bronze

Séc. XIV
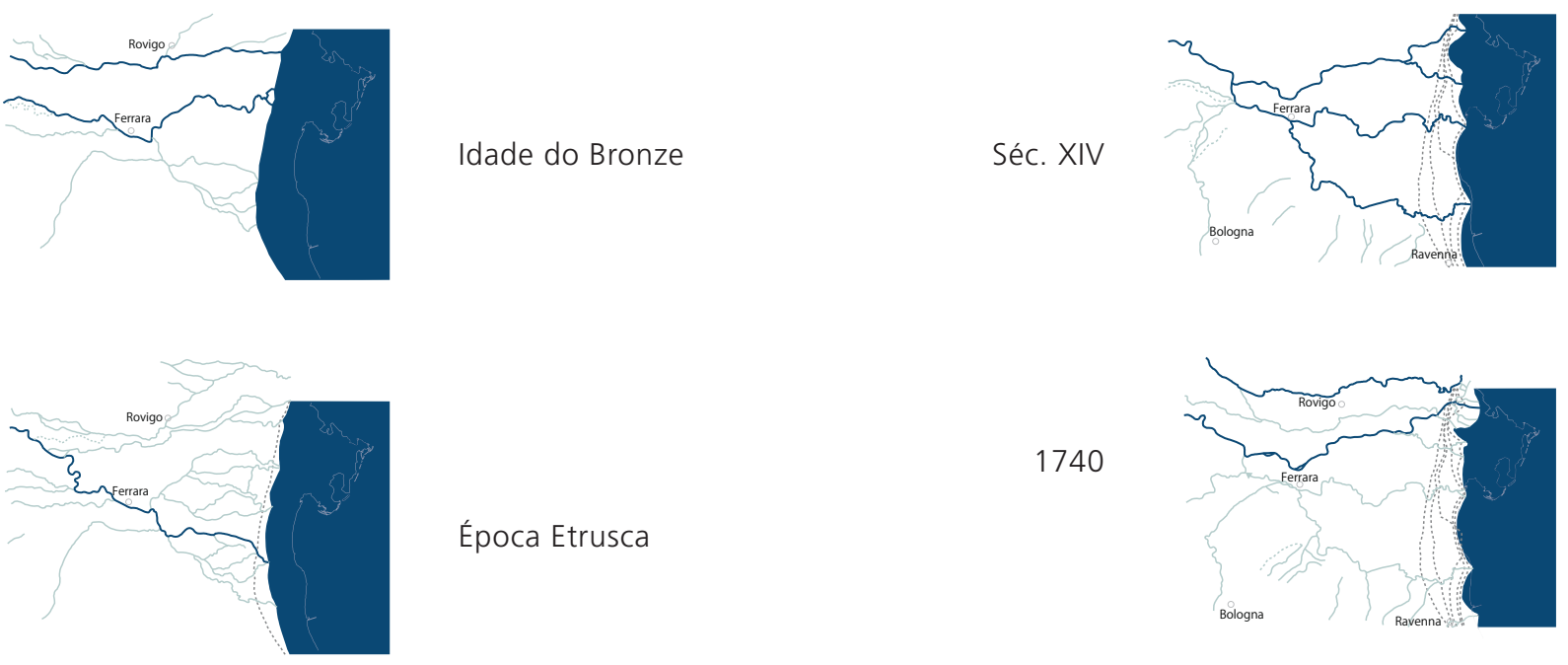

1740
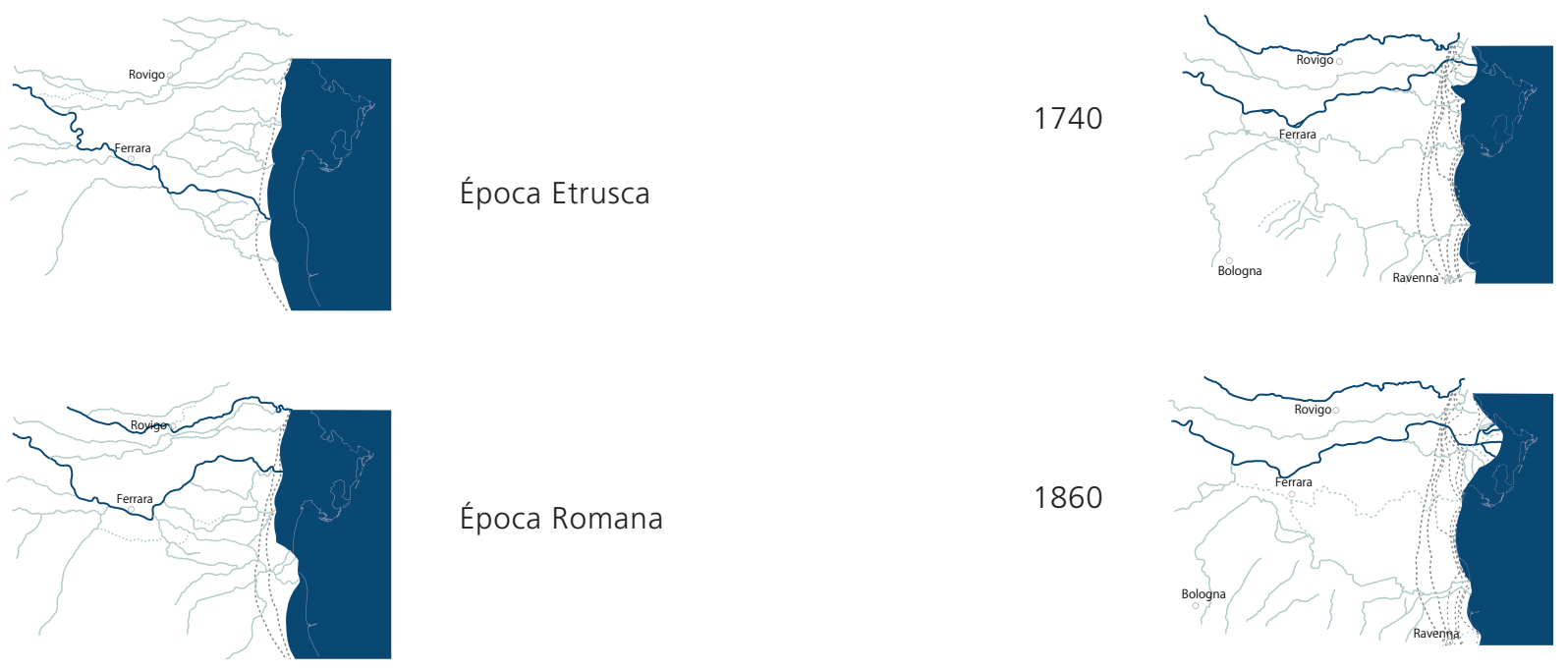

Época Romana
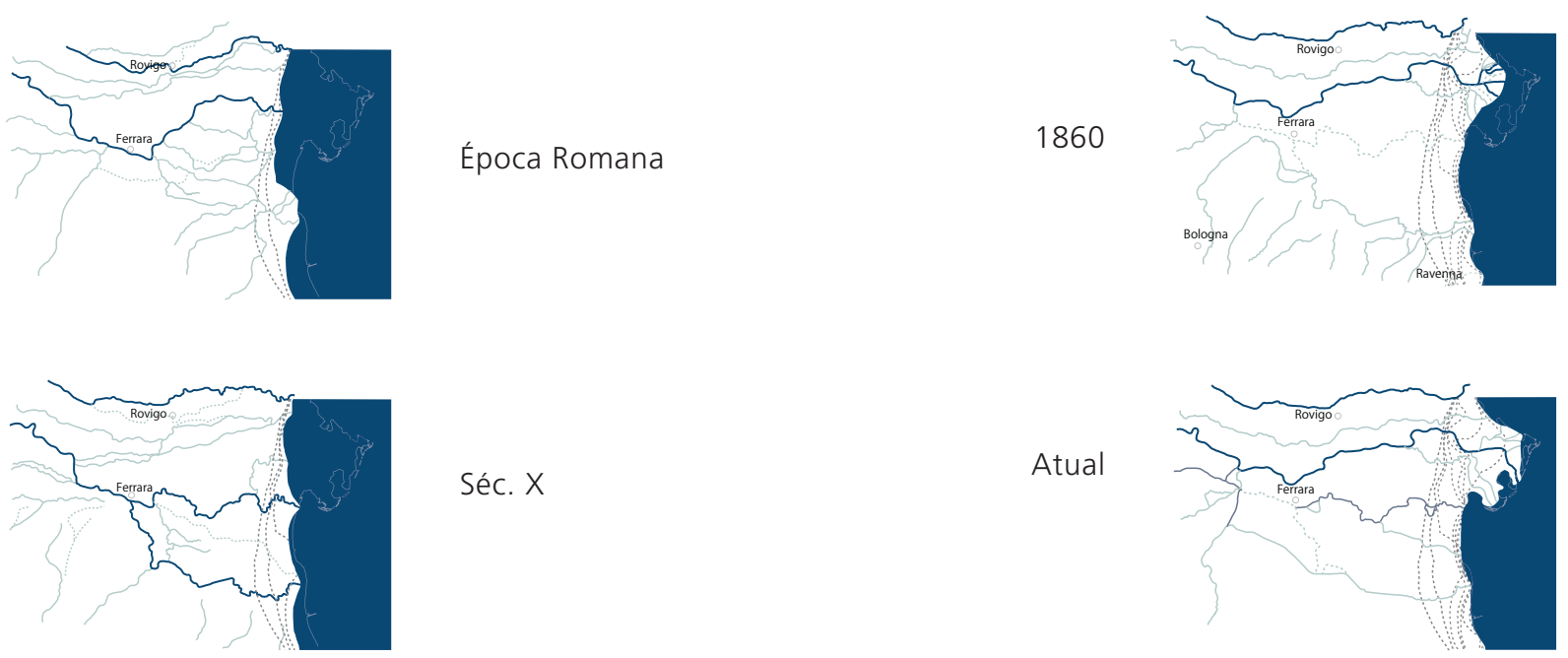

Séc. X

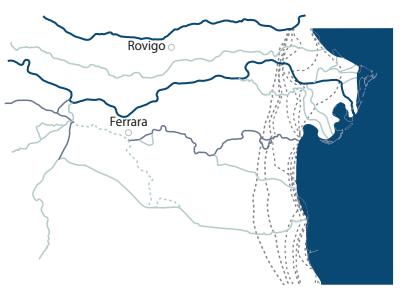

\section{Atualmente}

O território deste projeto tem a peculiaridade de ser uma junção de natureza e de intervenção humana, a qual se revelou imprescindível ao longo dos séculos, permitindo a aglomeração humana em terras continuamente oscilantes entre terra e água. Os efeitos resultantes dos eventos hidrográficos representam, de facto, a fundação do atual ordenamento territorial, tratando-se de um contexto cuja configuração presente, a nível de aglomeração e de ampla extensão geomorfológica, remonta a apenas dois séculos atrás. Um destino intimamente ligado às águas devido à posição em que se situa o território de Ferrara, no extremo oriental da planície do Pó, onde esta termina no mar Adriático: situação que tornou o território uma zona de colheitas e uma saída para o mar de 
um conjunto de rios do interior. O que tornou ainda mais complexa a situação hidrográfica local foi a enxertia, com uma direção substancialmente perpendicular em relação às directrizes fluviais da planície interna (orientadas na direcção oeste-este em conformidade com a altimetria do Pó), dos cursos de água apeninos provenientes do sul e espalhando-se, ao longo dos séculos, nos vales da baixa Emilia-Romagna. Além destas condições, existe também a altimetria específica destes territórios, completamente planos e em grande parte abaixo do nível do mar e, assim, sujeitos ao longo do tempo a repetidos e significativos fenómenos de abaixamento vertical, devido à presença de depósitos comprimíveis, fruto das águas que chegam e da extração indiscriminada de água e metano do subsolo, ocorrida no segundo pós-guerra.
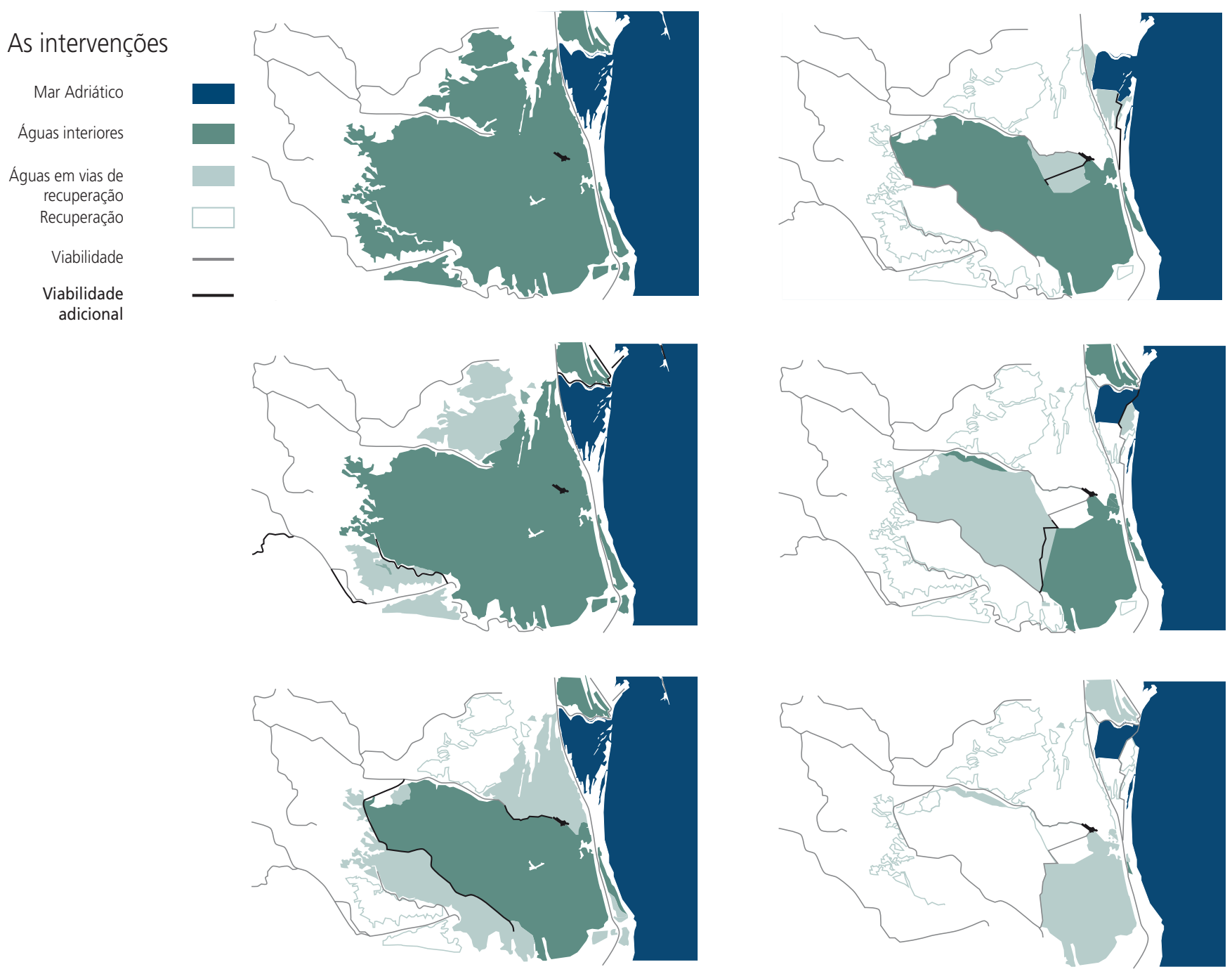


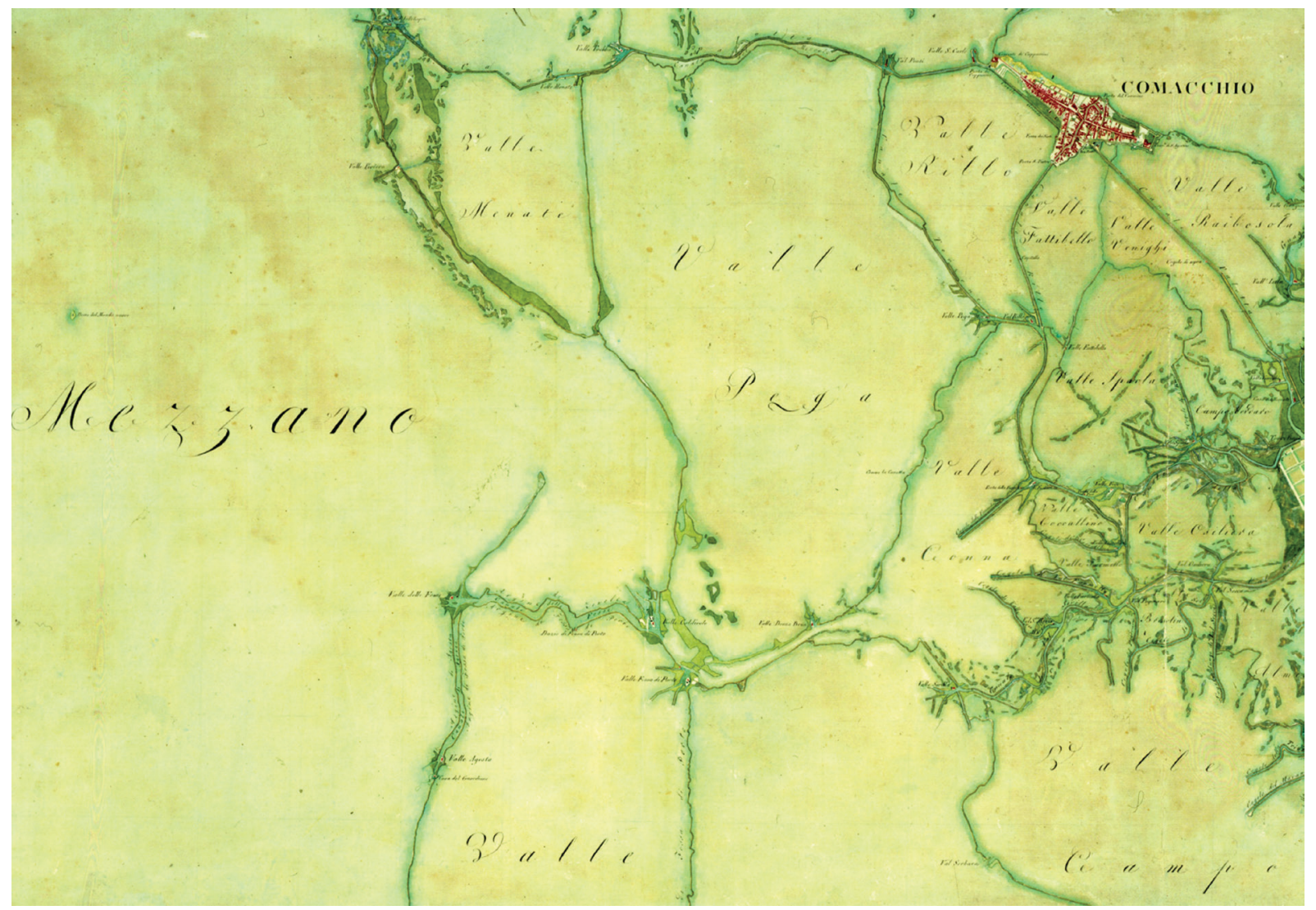

Extrato do Mapa do baixo Pó, 1812-14, Vienna, Kriegsarchiv, B VII a 284-286

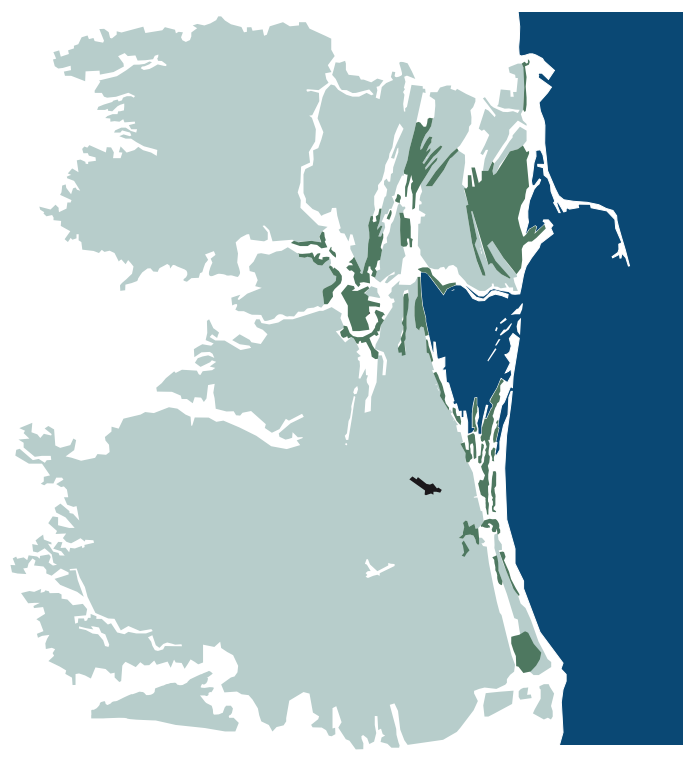

1814 - Estrutura da área arborizada

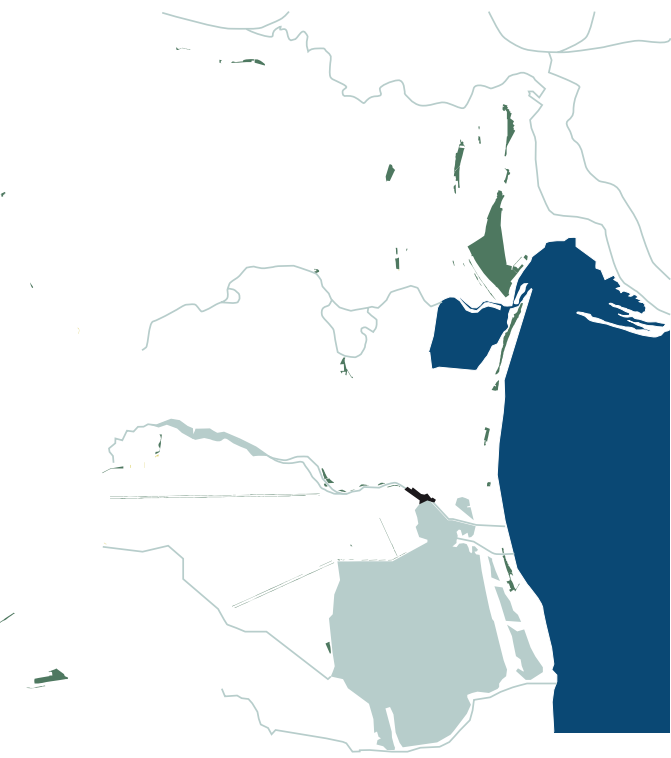

2012 - Área arborizada atual 
Nós existentes

Nós existentes

Passadiços em pedra sobre a àgua

Nós do projeto

Corredores do projeto

Corredores existentes

Linhas de árvores

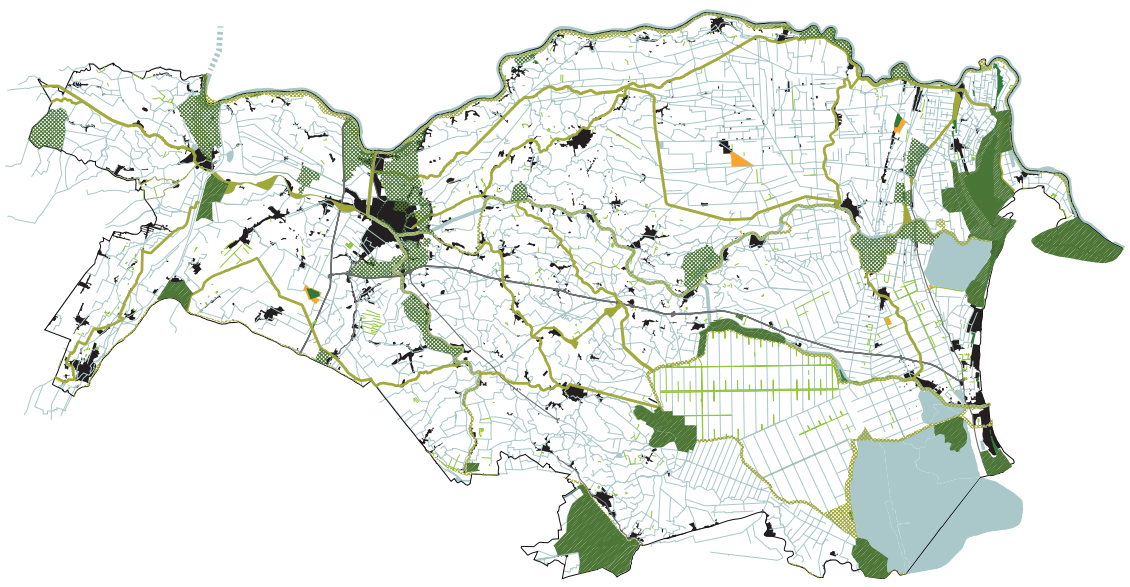

Tudo isto permitiu que o mar invadisse algumas destas zonas litorais anteriormente secas. Este conjunto de condições, associado à inevitável oscilação das diferentes condições climatéricas, e as estratégias do governo local provocaram uma sucessão de eventos que mudaram profundamente, de forma relativamente rápida, o território de Ferrara. Dada a multiplicidade dos fenómenos, muitas vezes contemporâneos e inter-relacionados, criou-se uma rede hidrográfica local extremamente complexa, que soube utilizar (e modificar) vias de água existentes, ligando-as a estruturas artificiais, enquadradas num projeto de território de grande dimensão.

O atual ordenamento físico é, de facto, fruto das respostas que o homem soube encontrar, ao longo dos tempos, para responder a uma série de problemáticas ligadas à rede hidrográfica, à subsidência natural e artificial, ao aumento do nível das águas do mar e à diminuição da sedimentação, devido ao aumento das escavações nos rios. Estas especificidades são hoje salvaguardadas por uma série de vínculos e tutelas, entre as quais a instituição, iniciada em 1988 com a Lei Regional, do Parque do Delta do Pó, e a inserção, em 1999, pela Unesco, na lista de Bens do Património Mundial. Como acontece quando a água está entre os elementos configuradores da morfologia de um território, a mutabilidade dos lugares sempre foi um traço saliente de Ferrara; contudo, é surpreendente a rapidez com que o território se modificou, se compararmos com outros contextos em que o ordenamento geomorfológico está traçado desde há muito tempo.

Ferrara sempre se caracterizou por ter um ambiente "brando", facilmente alterável por eventos naturais e artificiais: um território que se poderia definir de "argila", por essa capacidade de mudar de forma, devido a forças externas, mas também capaz de conservar os sinais do tempo; esta maleabilidade condiciona, de facto, a "memória", pronta a acolher novos eventos, mas rápida a esquecer. Trata-se de traços muitas vezes passageiros, não incritos à força, precisamente devido à extrema volubilidade destas terras, que podem ser apagadas por eventos sucessivos ou contrários, com a mesma facilidade com que surgiram. 
Muitas paisagens do passado são hoje vestígios, pedaços ou espécies disseminadas em contextos estranhos, cujo sentido permanece incompreensível para quem não tem os conhecimentos adequados para as interpretar: entre estas, estão numerosos elementos de valor ambiental e naturalístico, resquícios de uma progressiva artificialização do território, possível graças aos sucessivos trabalhos de recuperação. Em Ferrara, se por um lado a saída das águas permitiu o alargamento do território oriental e a infra-estruturação e aproveitamento para fins agrícolas, por outro apagou quase por completo uma paisagem de terras e águas única em Itália.

O núcleo central de Comacchio apresenta um ordenamento topográfico específico, de forma alongada, que faz lembrar o casco de uma embarcação: esta característica confere um ambiente particular à zona em que se encontra a cidade, fundada sobre algumas ilhas, treze segundo a tradição, separadas por canais estreitos e circundadas pelas águas baixas das lagoas costeiras.

Ao longo do tempo, a morfologia do tecido urbano modificou-se, originando, ainda que com as devidas especificidades do território, os mecanismos de evolução de outras realidades urbanas. Depois de uma expansão inicial, na sequência de prováveis trabalhos para o reforço das margens, as ilhas foram subdivididas devido à escavação de canais artificiais, numa espécie de "loteamento" das áreas emersas.

Apenas no decurso do século XX, após a construção das ligações rodoviárias entre a cidade e o território, ao que se acrescentaram os efeitos da reabilitação, tornando cada vez mais Comacchio numa cidade de terra firme, o número de canais reduziu-se devido à terraplenagem e os canais converteram-se em vias rodoviárias, o que implicou a demolição de várias pontes.

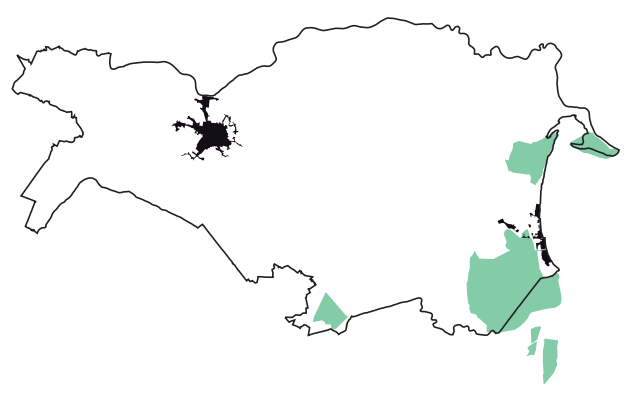

Zonas húmidas Ramsar

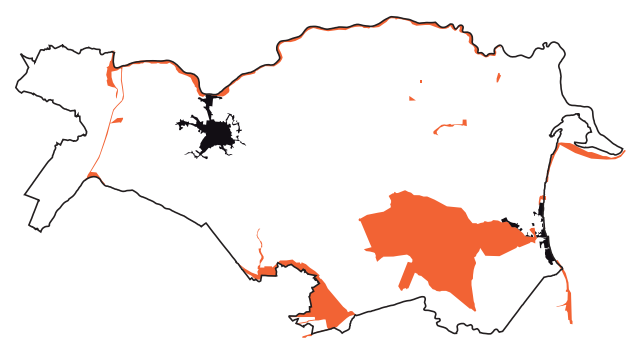

Locais de importância comunitária e Zonas especiais de proteção

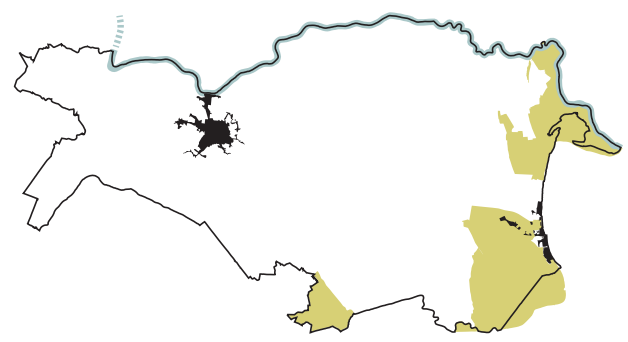

Parque do Delta do Pó 
Evolução do sistema urbano Comacchio-Costa

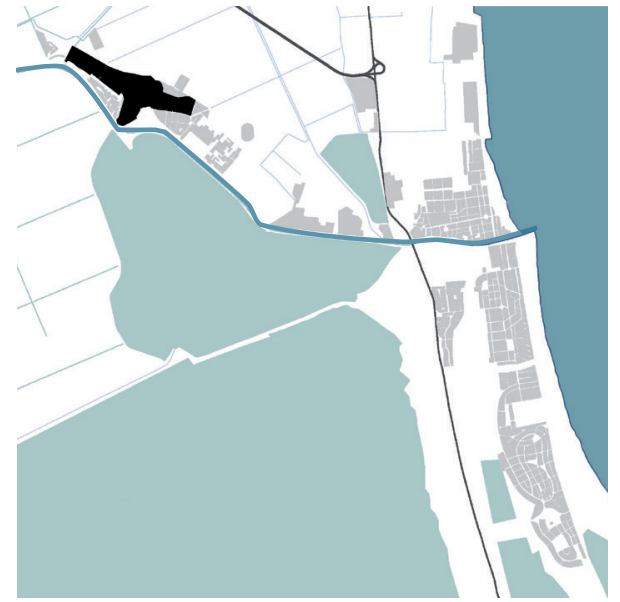

Anos 1940 - A Comacchio histórica

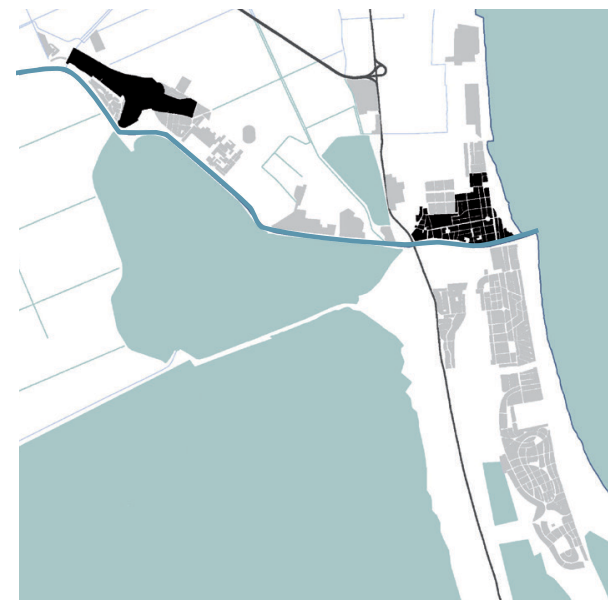

Anos 1950 - Reconstrução do Porto Garibaldi

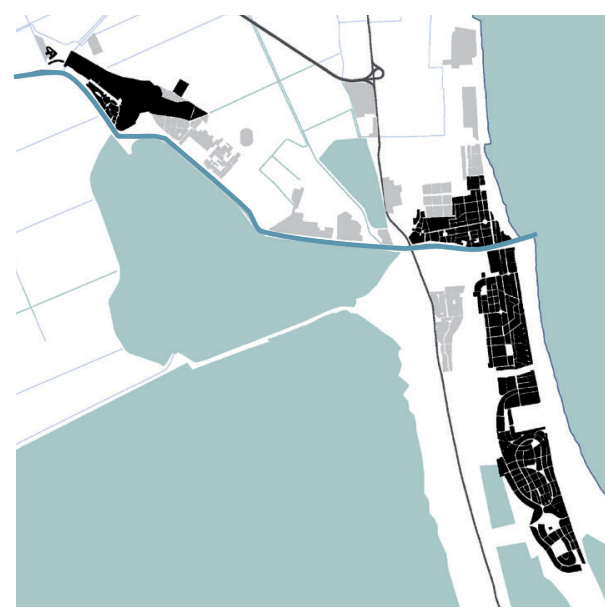

Anos 1960 - Construção da Costa Este e de Spina

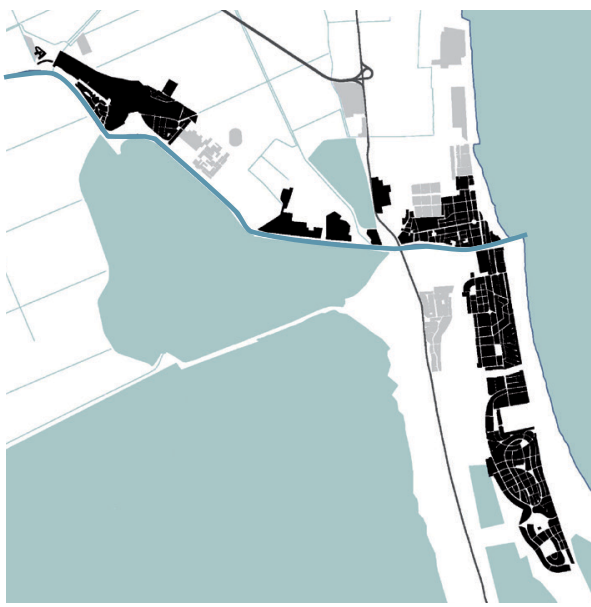

Anos 1970 - Primeiras implantações industriais

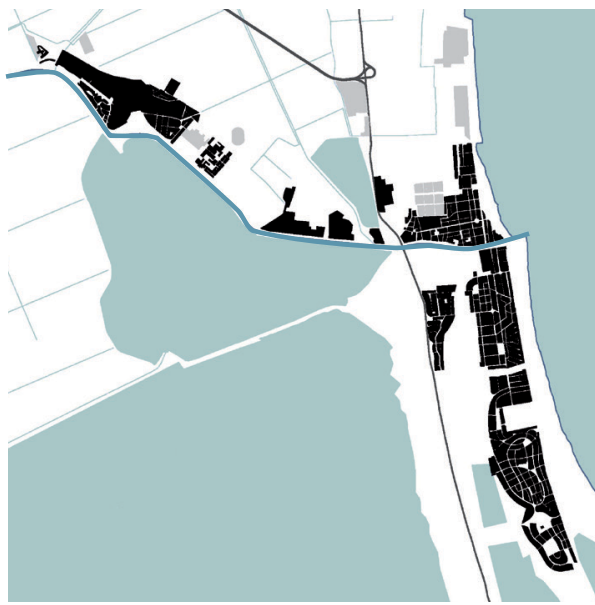

Anos 1980 - Construção dos quarteirões ERP

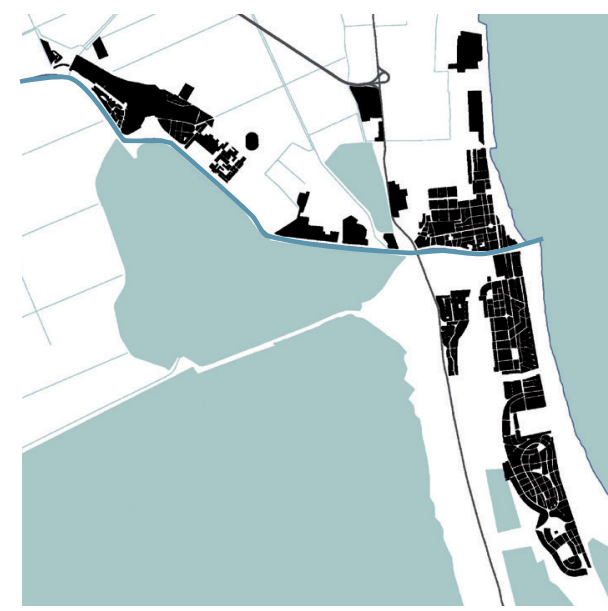

Anos 1990 - Nascimento da cidade do comércio 
A via Romea é uma barreira física entre o sistema costeiro e o interior, caracterizada pela ausência de travessias seguras e, portanto, por um elevado grau de perigo. Os elevados números de tráfego incrementam a sua natureza de elemento de rotura no território de comacchio.

Inverno: despovoamento da costa. As atividades urbanas distribuem-se principalmente entre Comacchio, Porto Garibaldi e Lido degli Estensi.

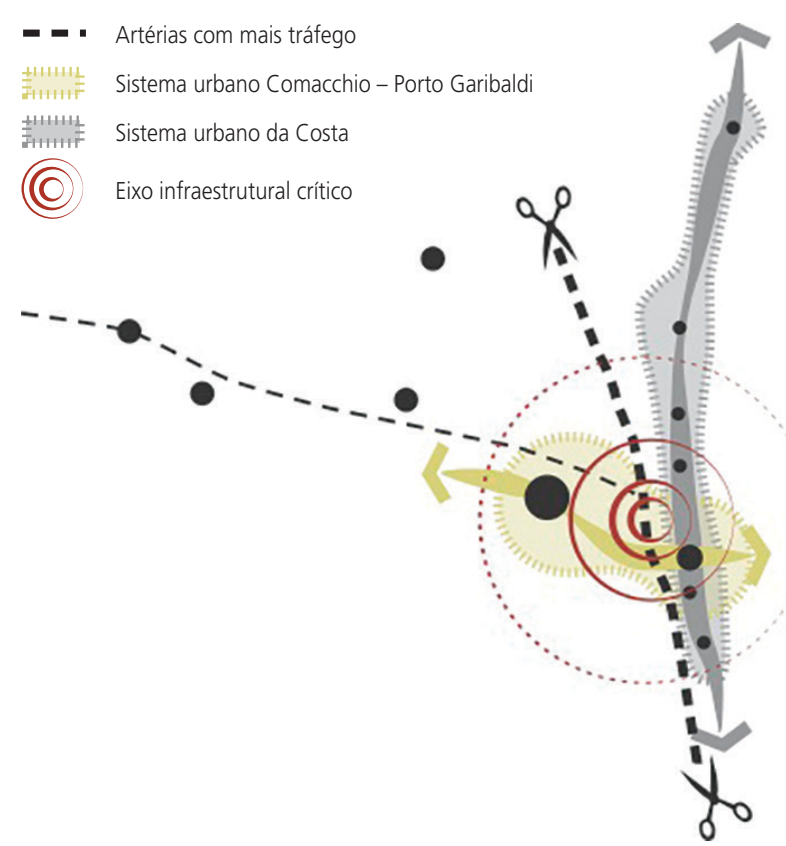

Verão: Repovoamento das praias e o consequente congestionamento de toda a faixa costeira.
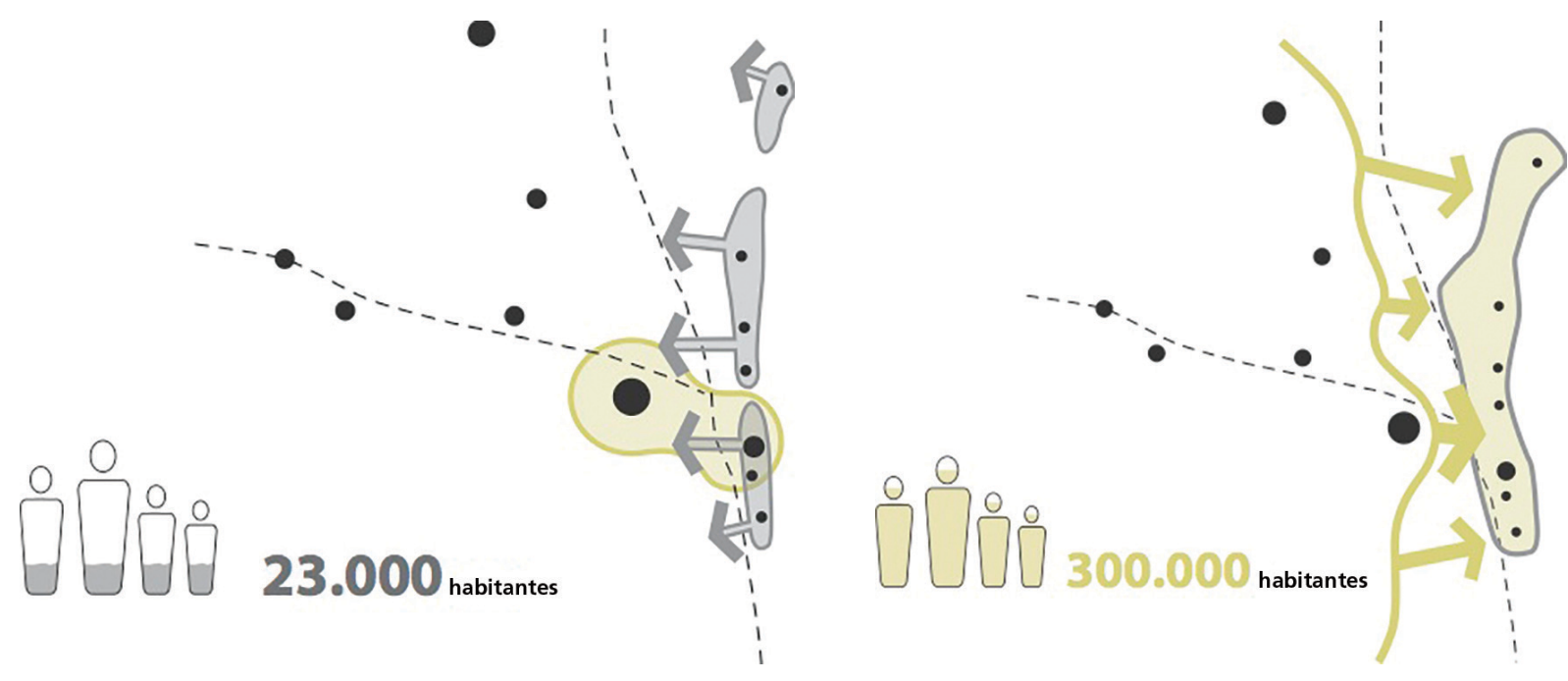


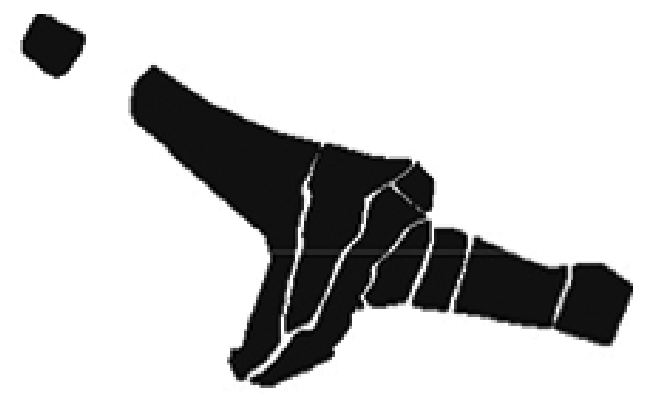

Núcleo primitivo de ilhas no interior do vale

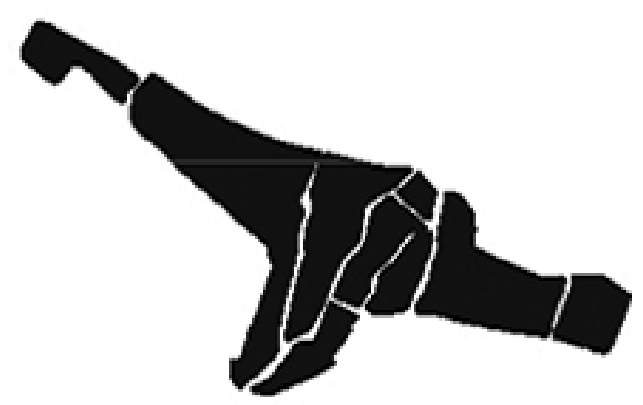

Ampliação das ilhas e criação de ligações entre os canais internos

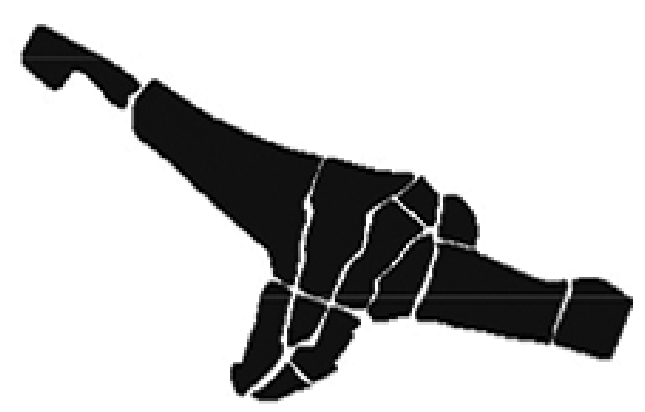

Fracionamento transversal

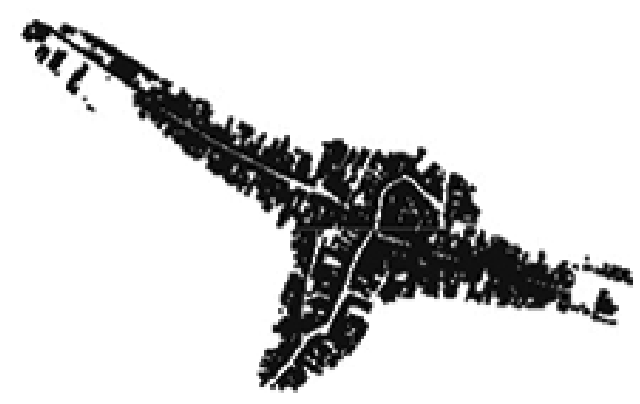

Configuração atual

\section{A evolução de uma cidade lagunar}

A cidade desenvolve-se, quase essencialmente, a partir de dois aspetos principais: o primeiro que parte da via Mazzini até à via Garibaldi, agora em estrada, mas no passado certamente um curso de água, direcionado de noroeste para sudeste; o segundo, perpendicular ao primeiro, formado por estábulos e canais centrais, desde a Via San Pietro à via Cavour, encontrando o primeiro precisamente no centro da cidade, a qual permanece dividida em quatro setores, num lugar marcado pelo perfil da Torre do Relógio. A aglomeração urbana desenvolve-se em redor destes dois percursos, fechado pelo canal perimetral e marcado, nas margens do eixo maior, por dois monumentos, ambos religiosos: a noroeste o complexo de Santa Maria em Aula Regia, com o conexo Portico del Cappucini e a sudeste o antigo Convento de Sant'Agostino, hoje à espera de uma desejada renovação.

\section{O património monumental}

O traço urbanístico mais característico de Comacchio foi-se formando após a devolução do ducado Estense ao Vaticano. Foi nesta época, entre os séculos XVII e $X V I I I$, que se ergueram os mais importantes exemplos de construção especializada e monumental que marcam, ainda hoje, o núcleo central da cidade: a Loggia del Grano, edificada na primeira metade do século XVII, a pequena Ponte delle Carceri, provavelmente construída entre 1631 e 1635, a mais famosa Trepponti, erguida em 1638, com projeto do arquitecto camarário Luca Danese, a Cattedrale, dedicada a San Cassiano e terminada em 1705, o Ospedale di San Camillo, finalizado em 1786. Há outras construções históricas que servem de coroa da cidade: o edifício de Pescherie Vecchie, o Palazzo Bellini, que acolhe atualmente a Biblioteca Civica, o Museo del Carico della Nave romana, emerso pela Valle Ponti. 


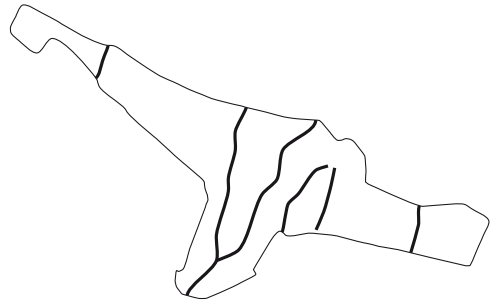

Primeiros canais paralelos

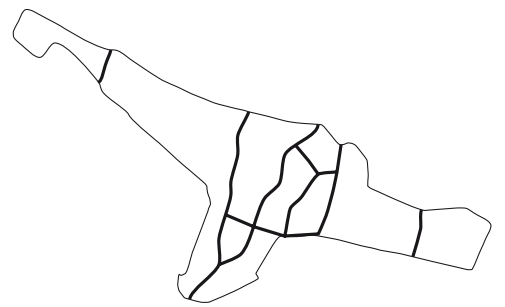

Época tardo-Romana/Medieval - as primeiras ligações

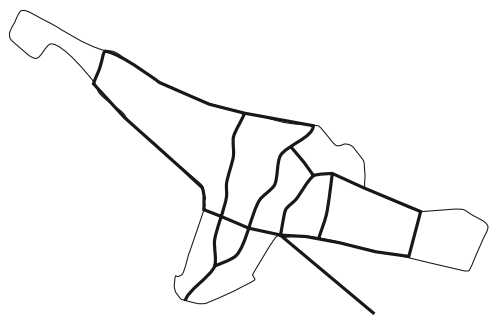

Época Renascimento/Barroco - arranjo dos canais perimetrais e criação do Canal Pallotta

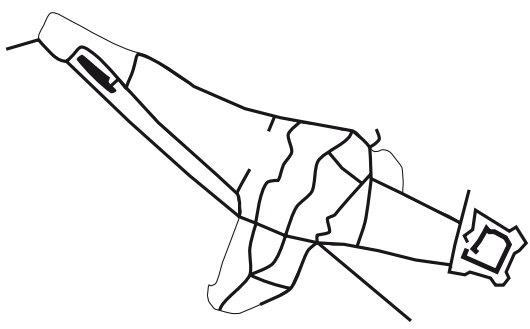

Séculos XVI/XVII - conclusão dos canais perimetrais e criação do canal artificial externo, Canal Grande da Francescona

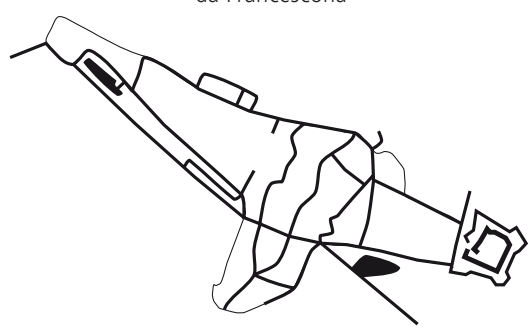

1817 - reforço de uma rede hídrica anteriormente desenvolvida no âmbito de pequenas intervenções no tecido urbano

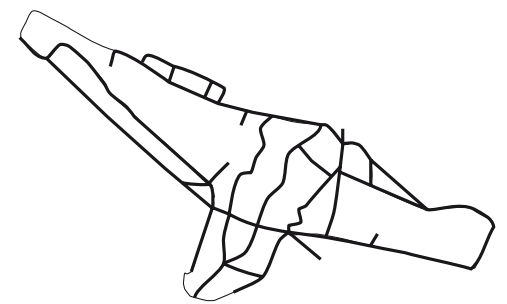

1860 - eliminação do fosso perto da Fortaleza Austríaca, o antigo Mosteiro dos Padres Agostinianos Descalços

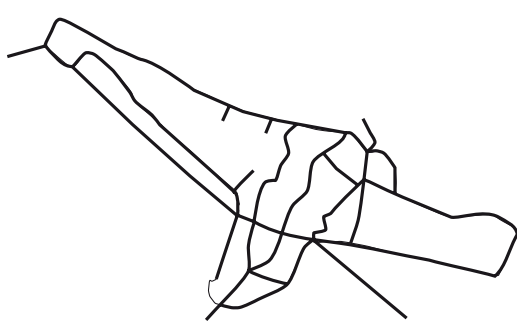

1940 - conclusão dos canais perimetrais

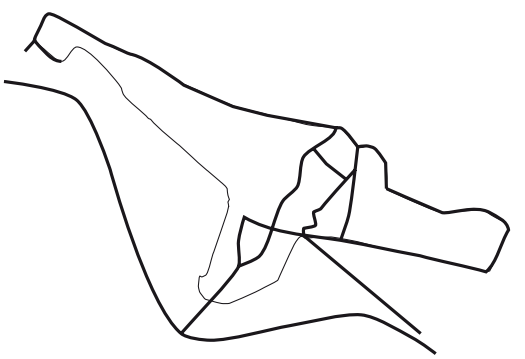

1974 - Redução da rede hídrica de superfície e criação de um canal navegável ligado aos vales
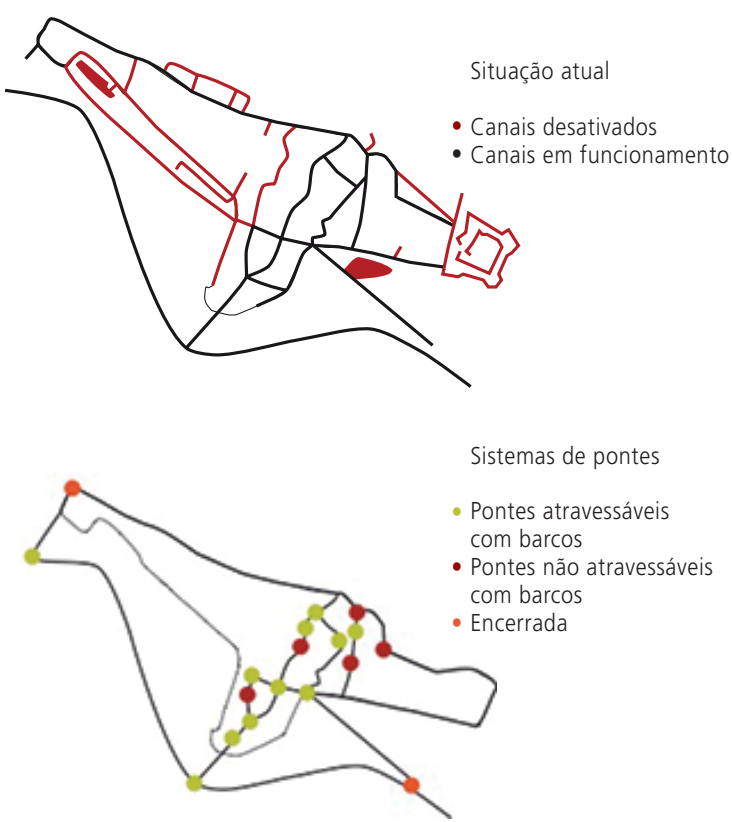


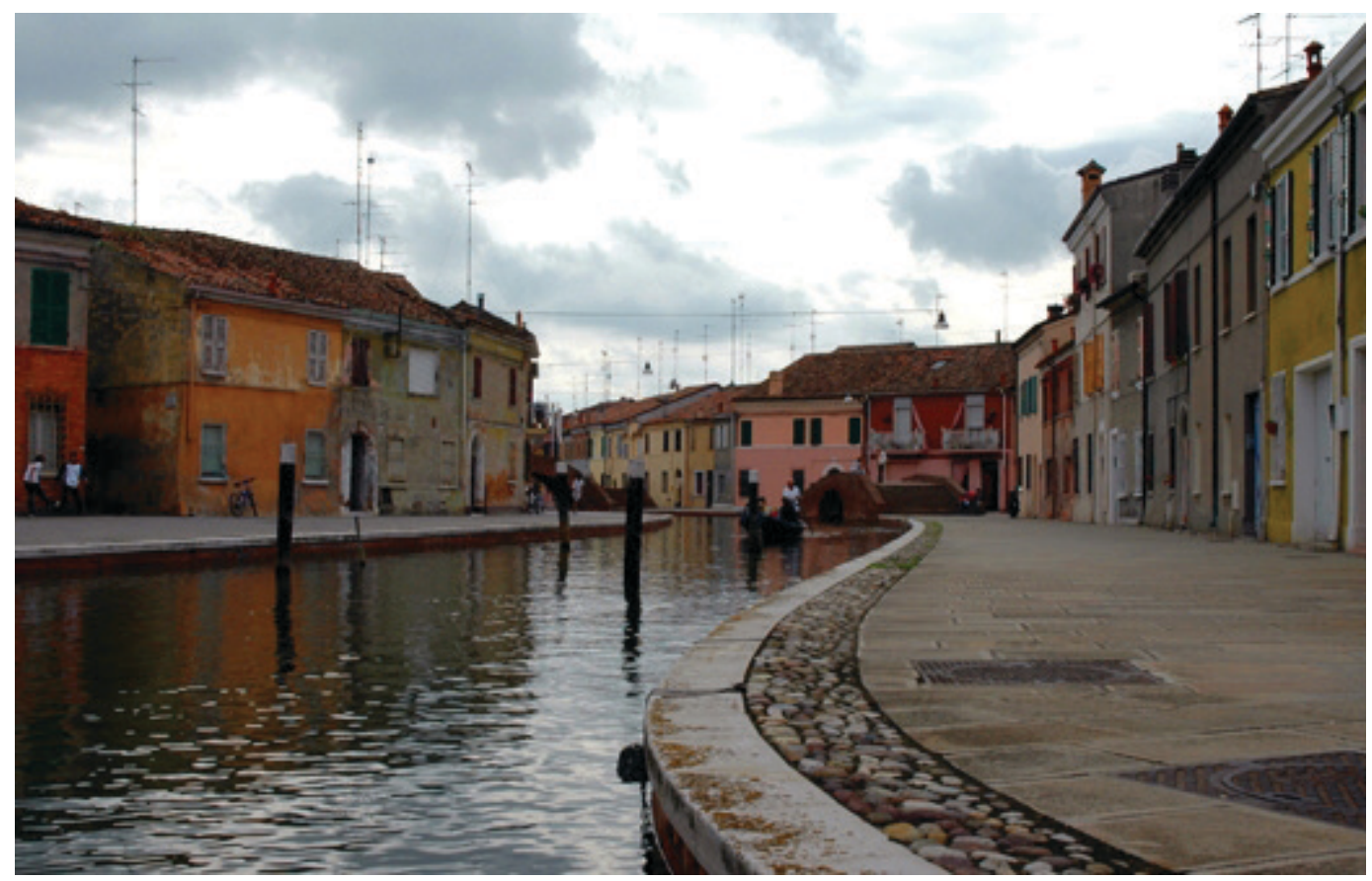

Canal Lombardo

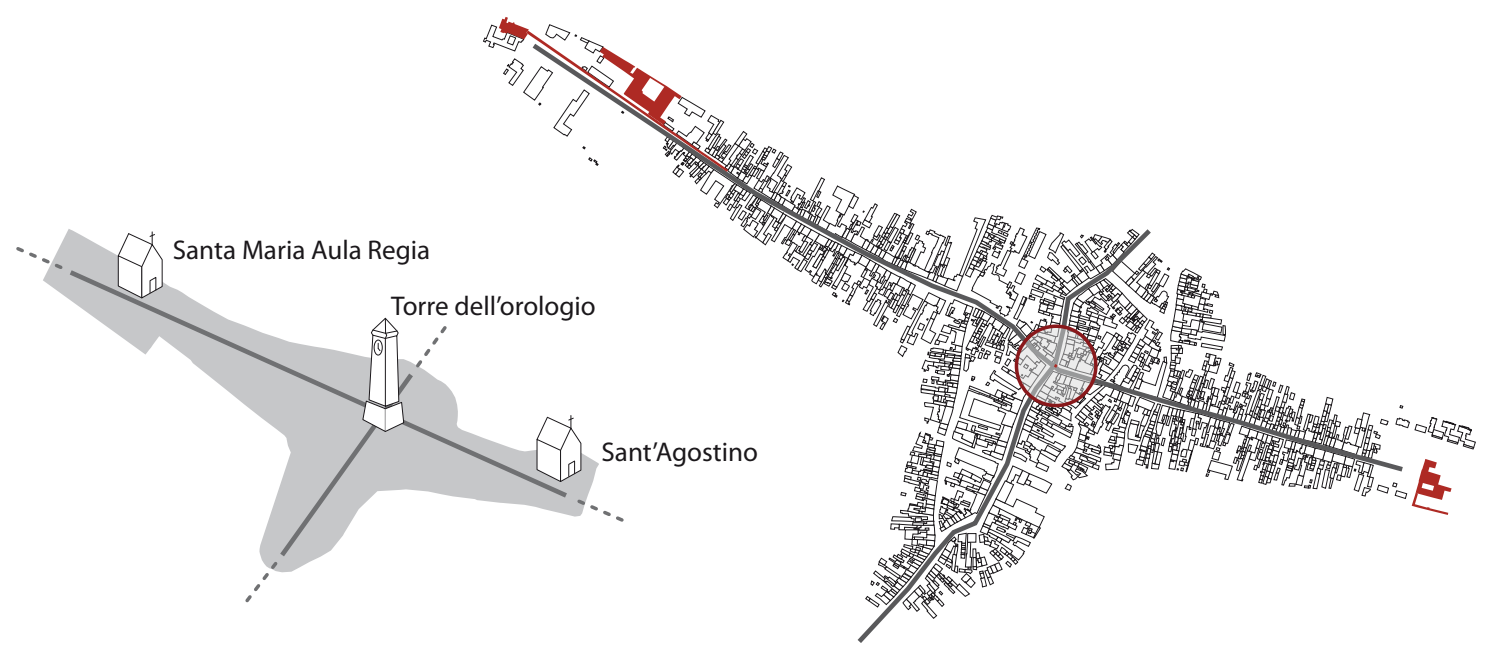

\section{Seguimento de habitações}

O tecido urbano do centro histórico tem uma configuração específica nas fachadas de frente para o canal perimetral: nestas zonas o meio urbano é composto por casas alinhadas ao longo de centenas de metros, de frente para a estrada, e habitações perpendiculares às anteriores, servidas por passagens 


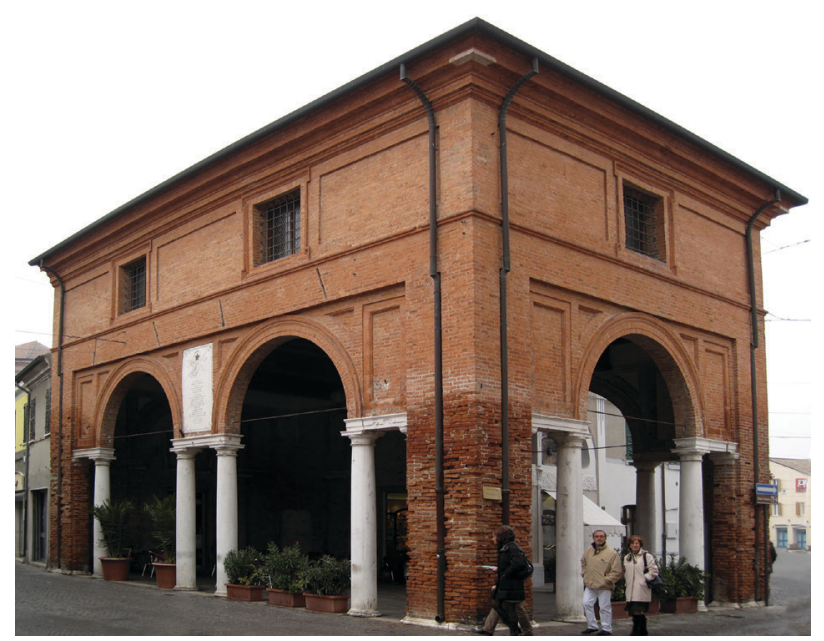

Casa do Trigo

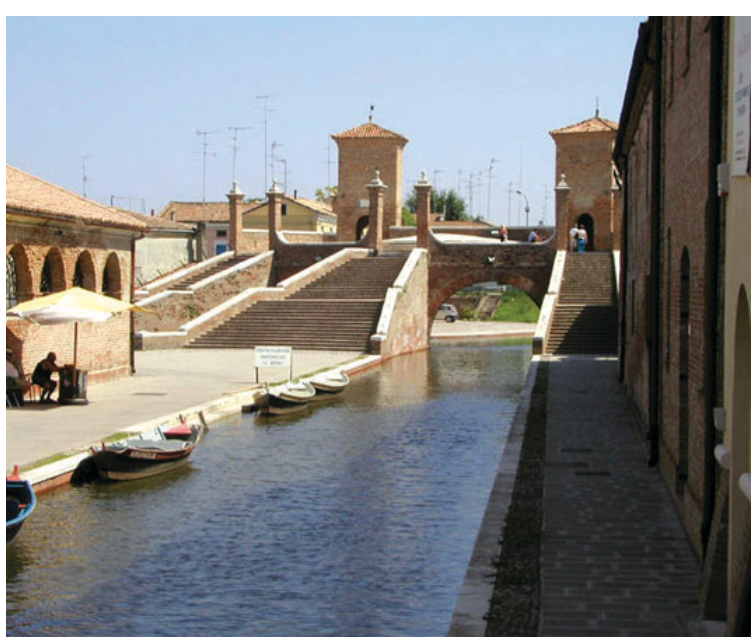

Três pontes

pedonais estreitas, às quais se acede através de pequenos vestíbulos, inseridos na fachada urbana, o que representa uma das características mais salientes de Comacchio. Depois das casas, geralmente, existem pequenas habitações que eram usadas para guardar equipamentos ligados à pesca e uma faixa verde utilizada como horto ou jardim, onde se punham a secar as redes da pesca. Hoje, muitas destas zonas são usadas para parques de estacionamento.

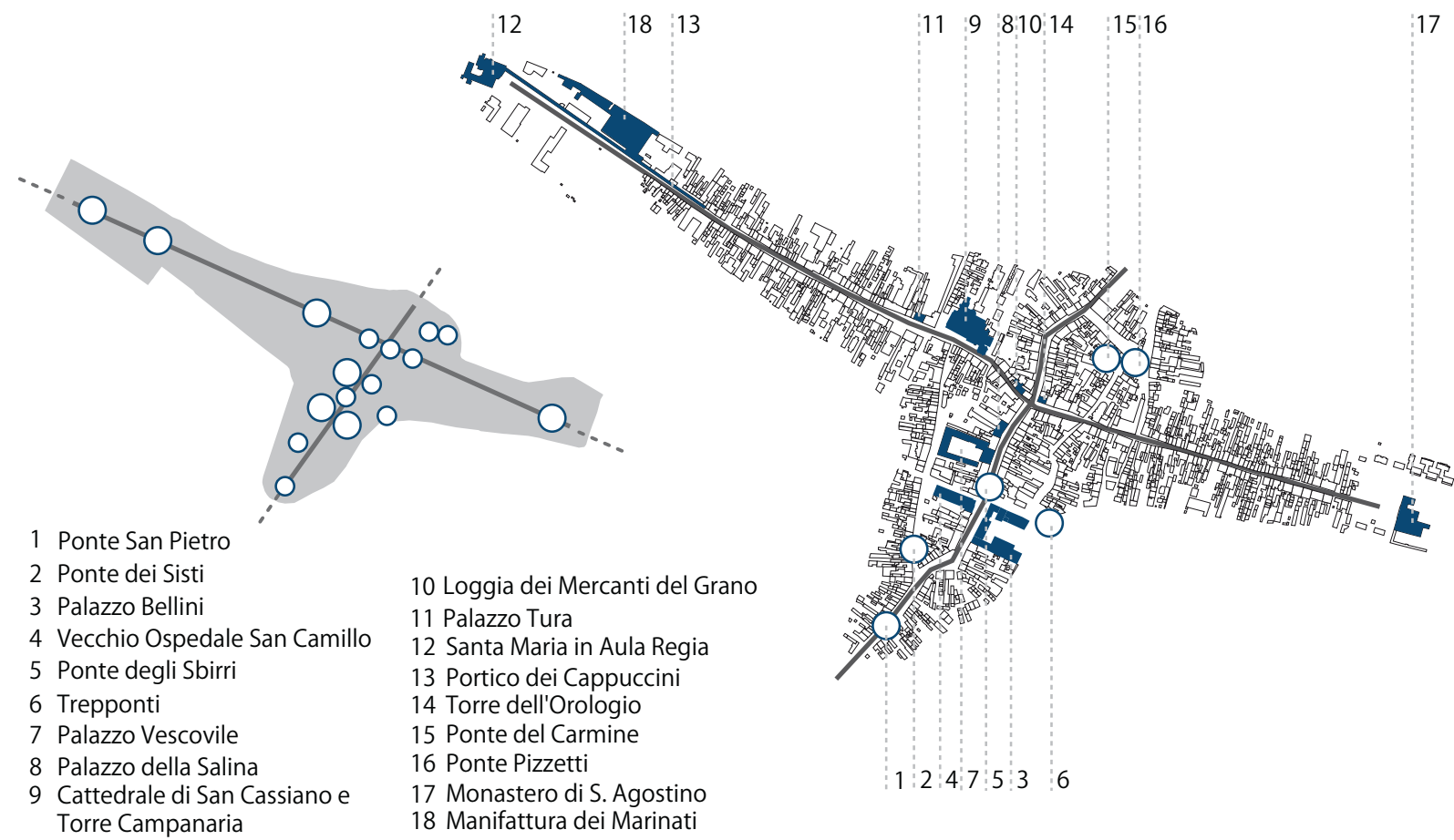



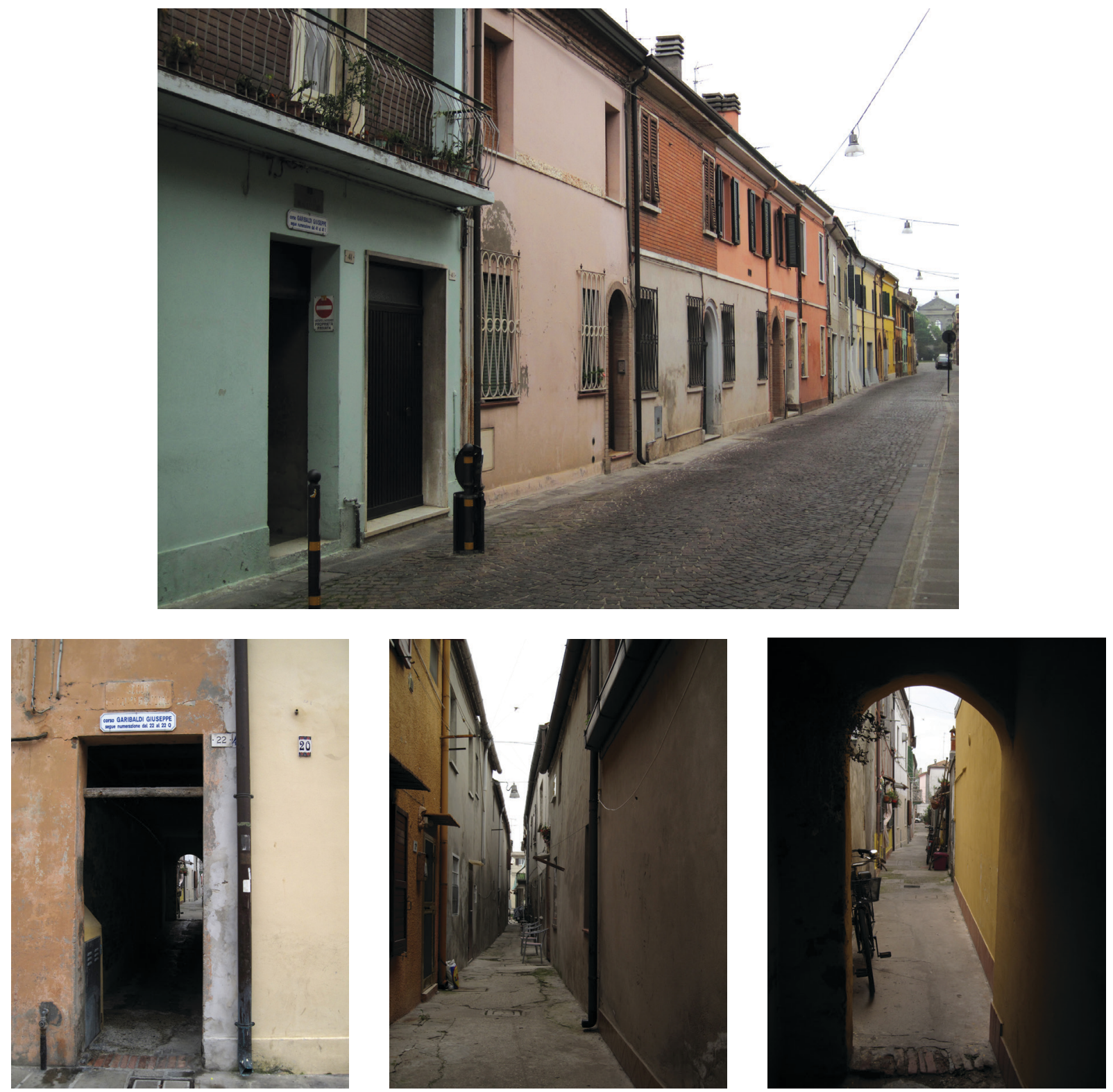

曧

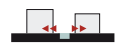

돌

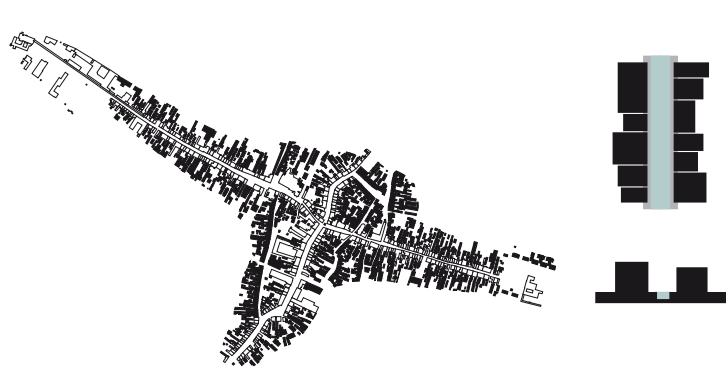

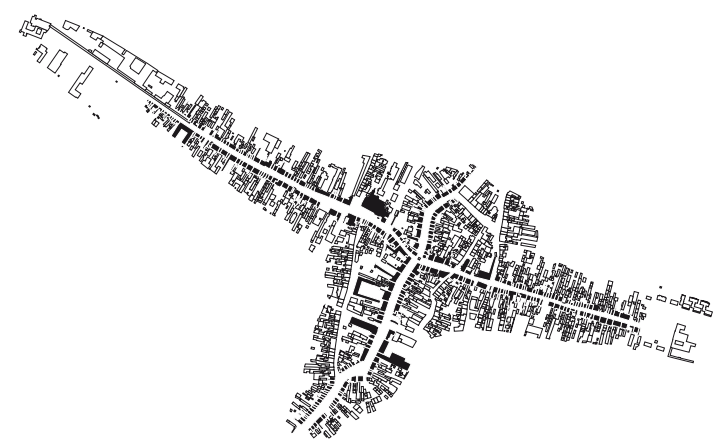




\section{Área de estudo}

Para o estudo escolhemos o sistema urbano composto pelo centro de Comacchio e as restantes cidades costeiras adjacentes (Porto Garibaldi, Lido degli Estensi e Lido di Spina) que constituem, atualmente, uma única conurbação. Esta situação tem origem numa série de causas:

- a presença, sobretudo em Porto Garibaldi e Lido degli Estensi, de uma população residente fixa durante todo o ano, que constitui a diferença mais evidente entre os dois centros e os restantes complexos turísticos do litoral de Ferrara;

- a deslocação, quase sempre para os aglomerados costeiros supramencionados, de uma série de serviços públicos e coletivos, entre os quais a escola municipal;

- a presença, entre Comacchio e o referido segmento da conurbação costeira, de uma série de equipamentos coletivos, além de territórios urbanizados, que criam uma ligação entre o centro do município e o litoral;

- as fortes deslocações pendulares quotidianas entre Comacchio e o litoral, consequência da necessidade de deslocação entre os diversos centros para se aceder à instrução, ao trabalho e ao tempo livre, impulsionado também pela pista ciclável na margem da estrada de Comacchio.

Este sistema representa, hoje, uma única conurbação, quer do ponto de vista da construção, sem dar soluções evidentes de continuidade entre os vários setores urbanizados, quer, sobretudo, do ponto de vista das dinâmicas sócio-económicas que ligam estes centros. A forte importância da água neste contexto urbano, a que se une a presença do Canal Navegável na via fluvial de Ferrara, que constitui uma verdadeira espinha dorsal de toda a conurbação, tornou este caso numa interessante área de estudo para se ativar a fase de inquérito e o laboratório de projeto, previsto pelo documento programático do Projeto "Água como património".

Esta escolha foi reforçada pela existência, nesta área, de zonas de degradação ambiental, urbana e sócio-económica que necessitam de urgentes intervenções de requalificação, que podem ser pensadas ao longo do laboratório de projeto.

\section{Área ex Eridania}

Esta antiga zona industrial está hoje desativada, após o fecho em definitivo da indústria de açúcar, em 1993, e a consequente demolição de algumas fábricas dez anos depois. De seguida, esta zona foi reabilitada. Este caso é interessante do ponto de vista da intervenção de requalificação urbanística e ambiental, dada a sua localização à entrada de Comacchio, ao longo de importantes vias de acesso ao centro habitacional, dispondo já de infra-estruturas de rede. Este local assume maior valor graças à presença, no subsolo, de vestígios arqueológicos do porto da antiga Comacchio que poderiam, se adequadamente recuperados, enriquecer a zona e convertê-la num ponto turístico. 


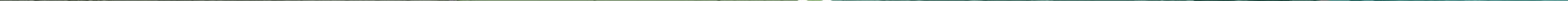




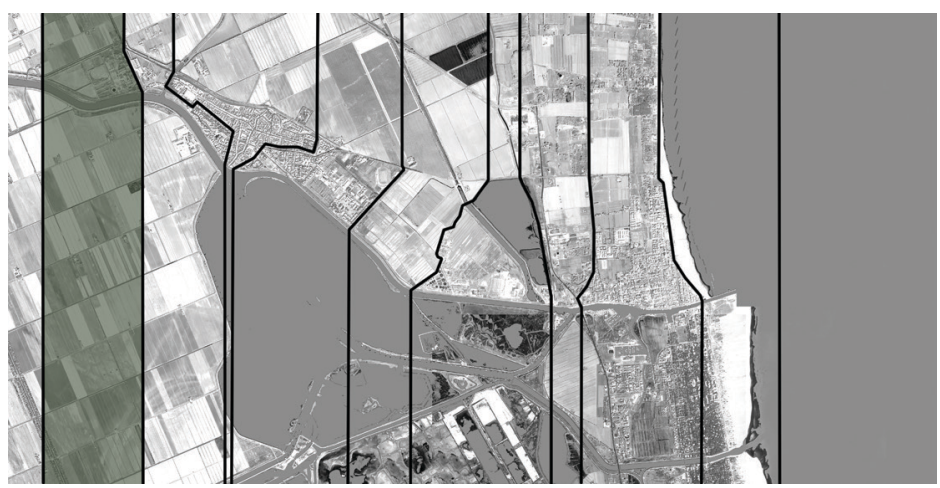

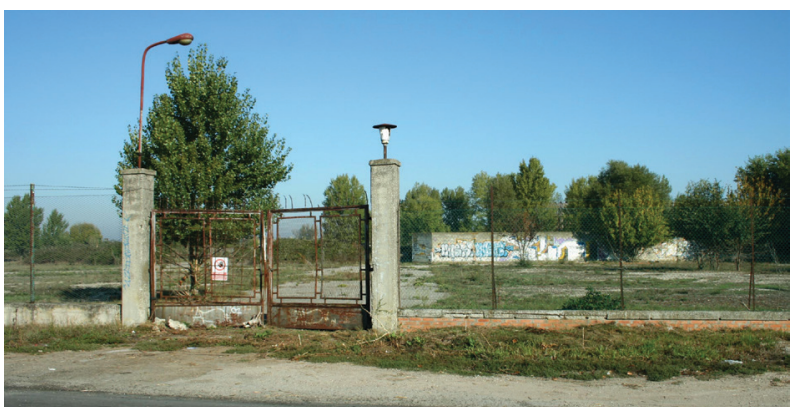

Entrada na SP15, "Via del Mare"

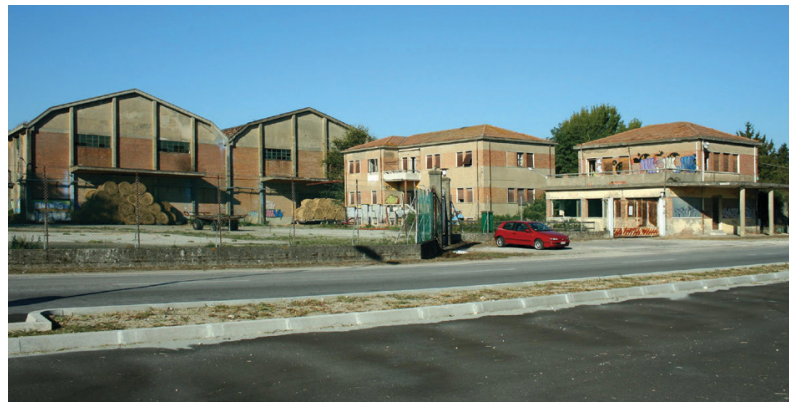

Complexo de edifícios atuais

\section{Habitação social}

O complexo de habitação social ao longo da Via Spina apresenta problemas evidentes de degradação estrutural e urbanística, devido à deterioração dos edifícios, à proliferação de anexos sem qualidade arquitectónica, à existência de edifícios de carácter produtivo, agora desadequados numa função prevalentemente residencial e, por fim, devido à ausência de projetos e manutenção dos espaços públicos e das relações, que provocaram um sentimento de negligência, além de fenómenos de apropriação privada sem justificação.

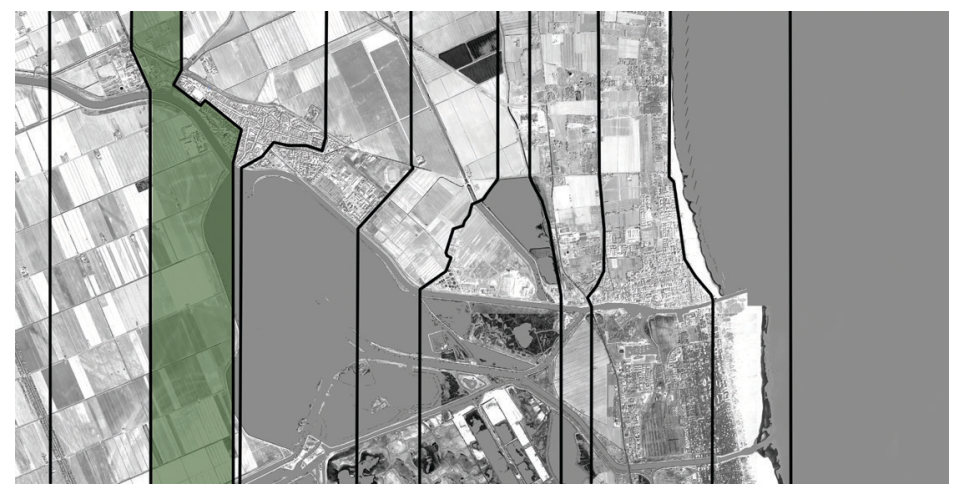




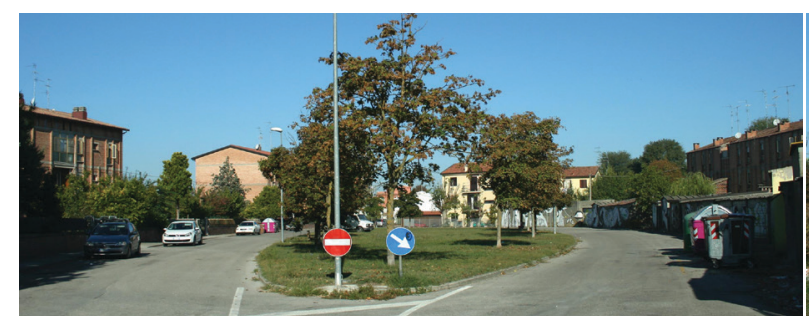

Zona verde, Via 2 de junho

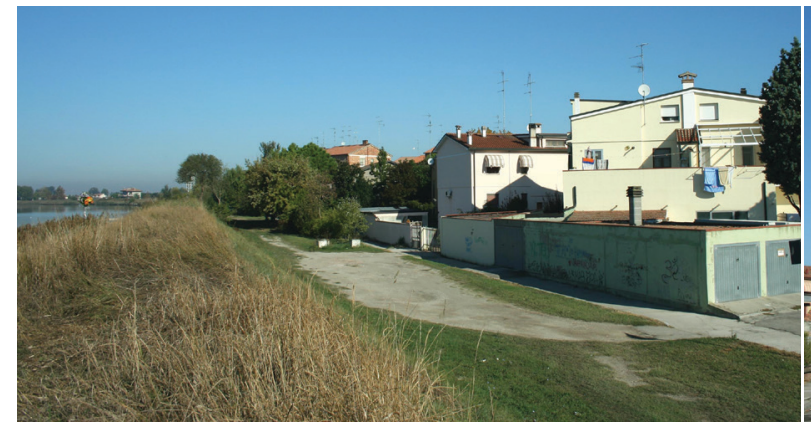

Visto do topo do represa

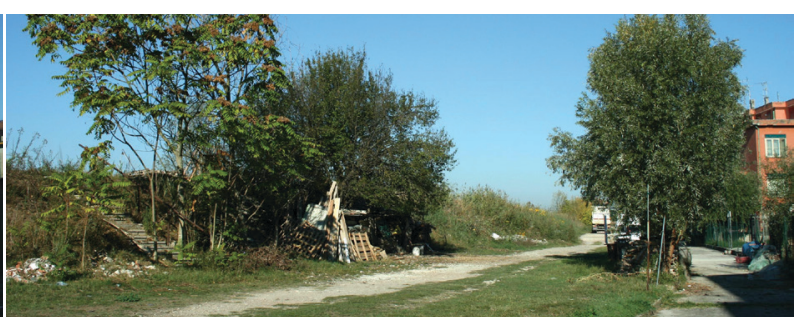

Vereda ao longo da represa

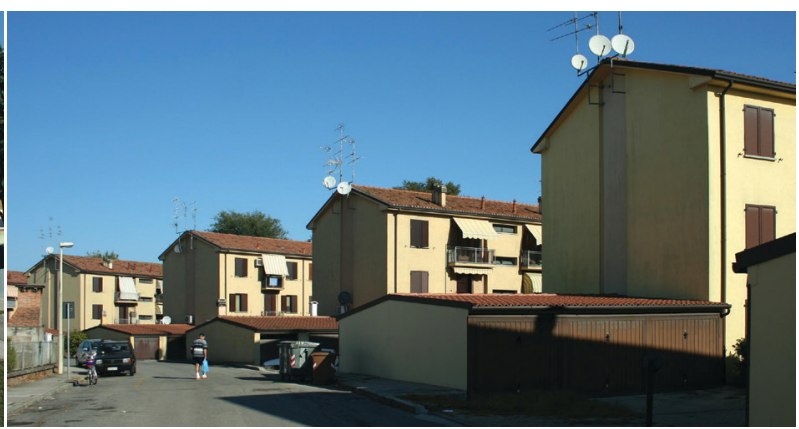

Habitações ao longo da Via Spina

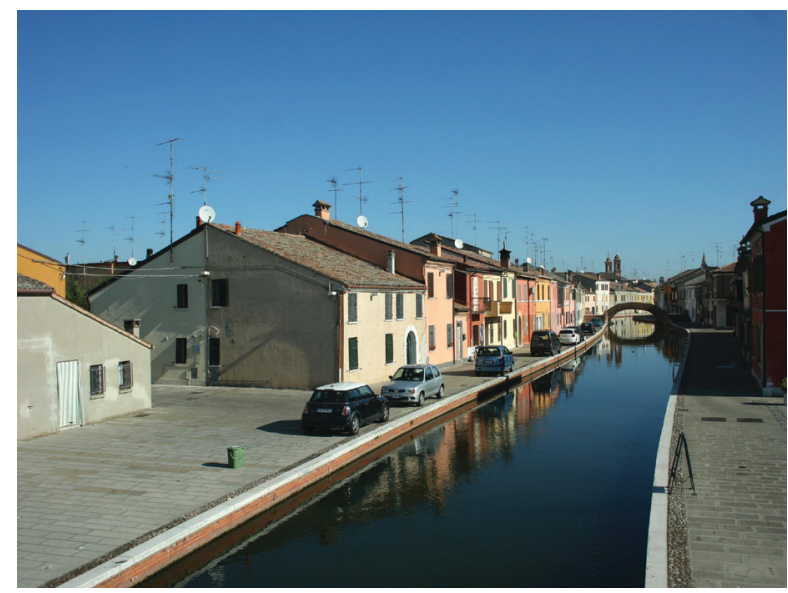

Canal Lombardo

\section{Centro histórico}

A relação entre o centro histórico de Comacchio e os seus vales parece, hoje em dia, quase inexistente, mesmo sob o ponto de vista perceptivo, se excluirmos o único ponto de observação, uma pequena torre de madeira junto à ponte de San Pietro. O complexo monumental de Santa Maria em Aula Regia, junto com o Portico dei Cappuccini, ao longo do qual se situa o acesso ao museu Manifattura del Marinati, necessita de intervenções de requalificação urbana, de forma a eliminar alguns edifícios de carácter produtivo desnecessários que em nada contribuem para a qualidade urbana da área. 


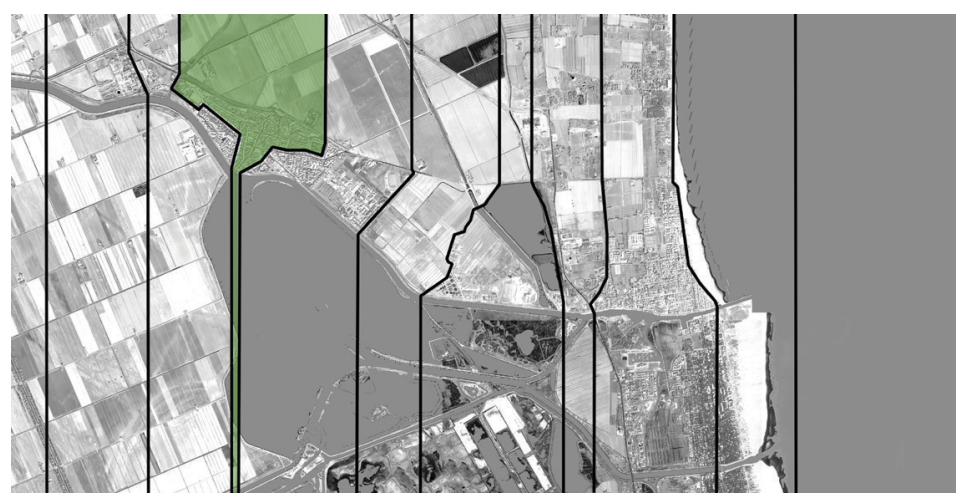

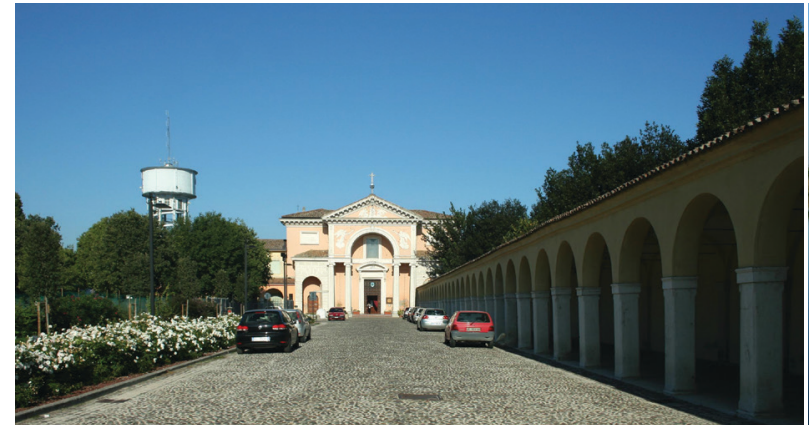

Santa Maria em Aula Regia e Pórtico dos Capuchinhos

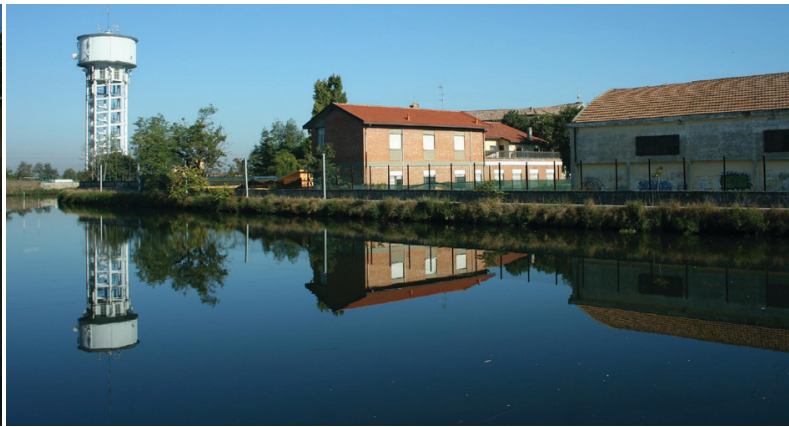

Doca turística ao longo da SP1

\section{Periferia}

As áreas residenciais construídas, ao longo do século XX, na parte oriental do centro histórico apresentam problemáticas recorrentes, do ponto de vista da qualidade urbana, de muitas outras periferias. Uma situação que parece ainda mais evidente no Quartiere Raibosola, onde se situam várias habitações sociais destinadas às classes mais desfavorecidas; são precisamente estes motivos que provocam a degradação dos espaços abertos e de convívio. Também algumas intervenções públicas, entre as quais o estádio municipal, não souberam melhorar a qualidade urbana. Ao invés, acentuaram a desordem perceptiva, fruto de projetos incoerentes e espaçados no tempo.

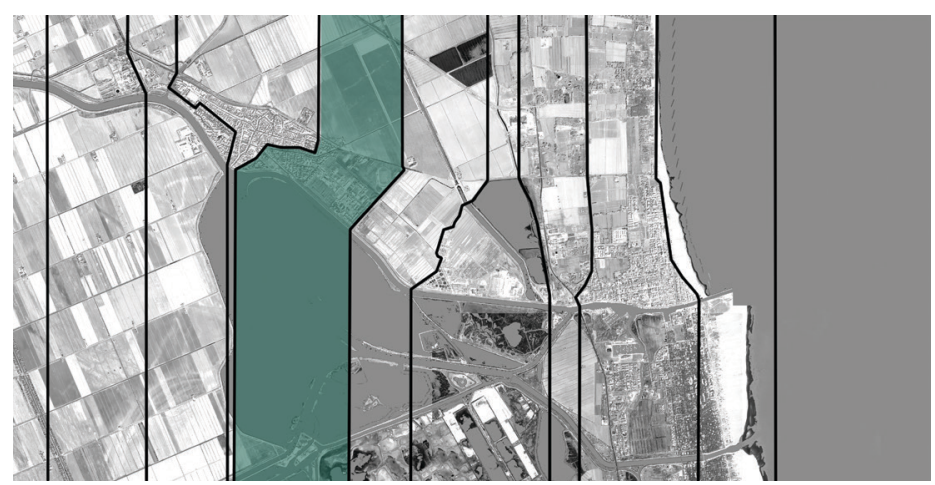




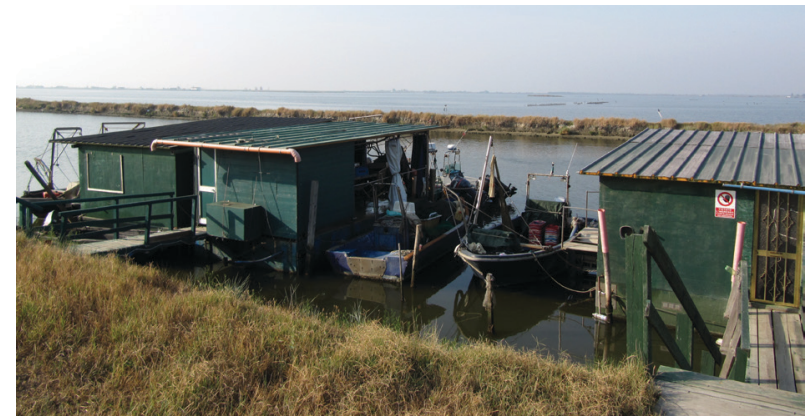

Os vales na borda do bairro Raibosola

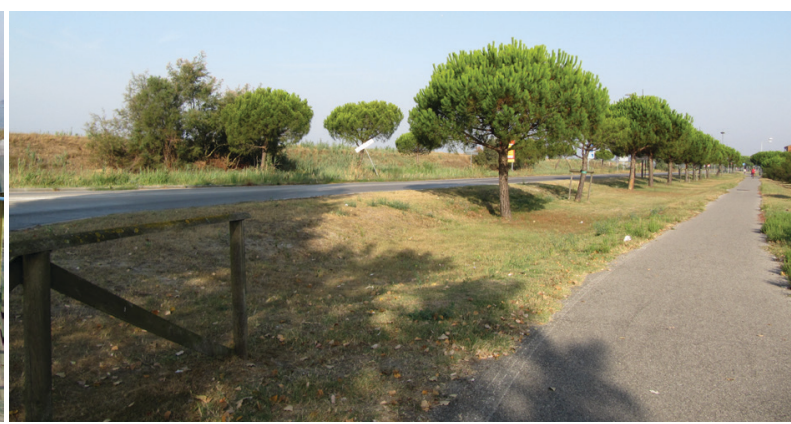

Pista ciclável ao longo da estrada SP1 - Estrada de Comacchio

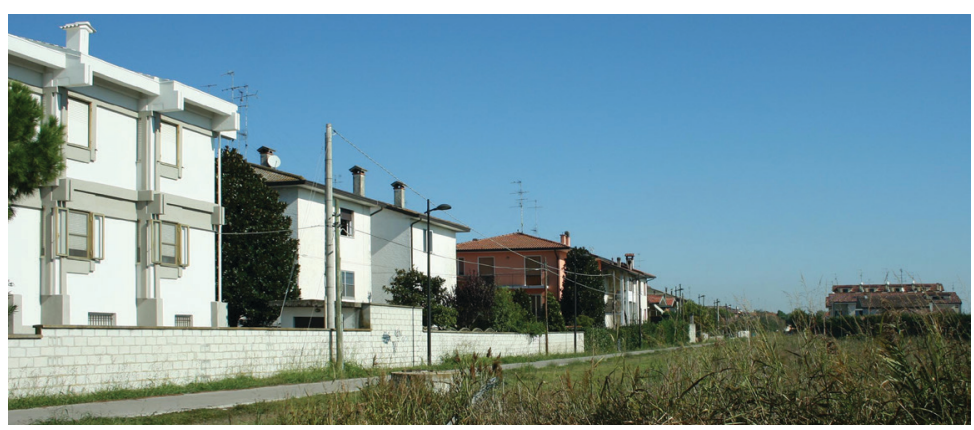

Habitações do bairro Raibosola

\section{O campo}

As zonas agrícolas residuais, entre Comacchio e a conurbação costeira, apresentam os mesmos fenómenos de degradação sob o ponto de vista ambiental e paisagístico da periferia do lado este: ausência de uma utilização efetiva do espaço, devido à má qualidade dos terrenos, que são pouco produtivos e com altos níveis de sal, a ausência de uma demarcação clara das zonas, a insuficiente demarcação das infra-estruturas existentes e a deslocalização de funções desadequadas. Esta zona está completamente desajustada com os elementos em seu redor, entre os quais os vales, tapados à vista por uma retenção de águas em betão. Se devidamente repensado, este local poderia ser uma oportunidade para a construção de um parque agrícola, ao serviço do centro habitacional e da conurbação costeira.

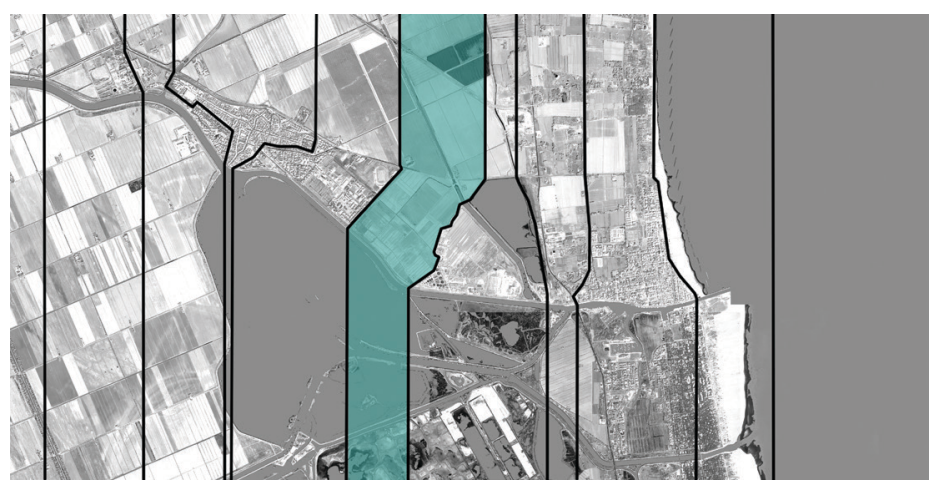




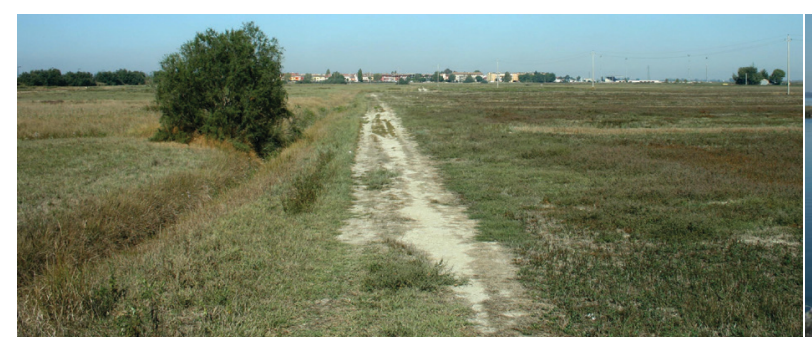

Paisagem agrícola residual entre Comacchio e a costa

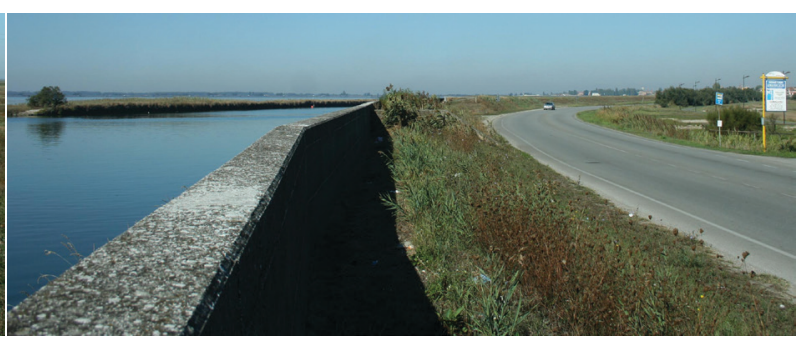

Represas artificiais ao longo da "Estrada de Comacchio"

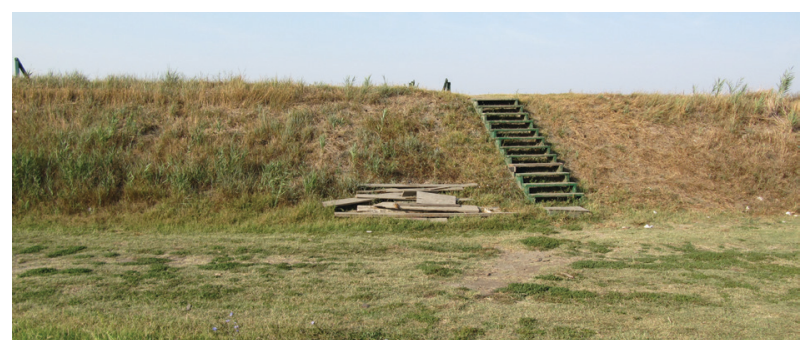

Terraplanagem do canal navegável

\section{Indústria}

Este setor tem como principal função a produção. Está localizado na parte ocidental da Strada Statale "Romea", e apresenta os mesmos fenómenos de degradação encontrados noutros transeptos da área de projeto.

Esta situação resulta também da crise económica, a qual afetou o setor produtivo e deixou atrás de si edifícios vazios, como é o caso da indústria Cercom. A mistura de atividades artesanais, a construção de má qualidade e os equipamentos públicos criam uma paisagem urbana caracterizada por uma desordem perceptiva evidente. Esta situação está presente também ao longo da via fluvial de Ferrara, que necessita, hoje, de intervenções de recuperação das margens, com a remoção de volumetrias não compatíveis com a protecção ambiental dessas zonas.

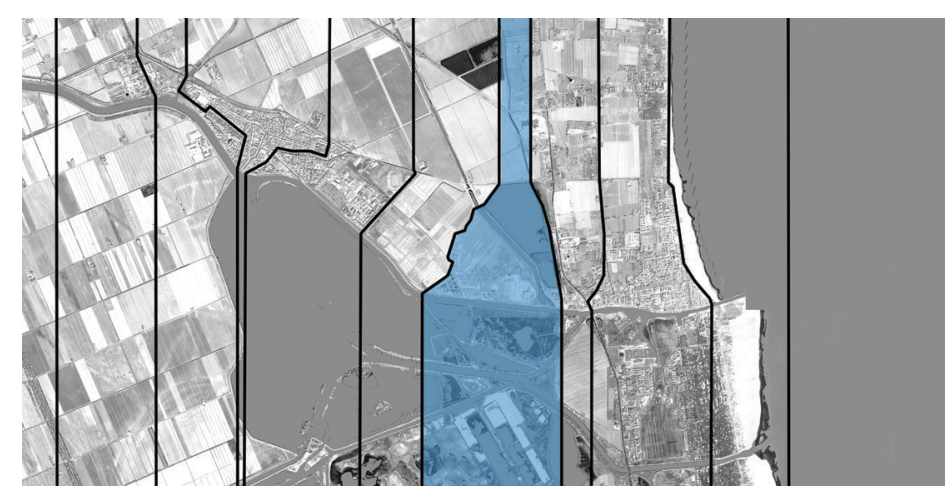




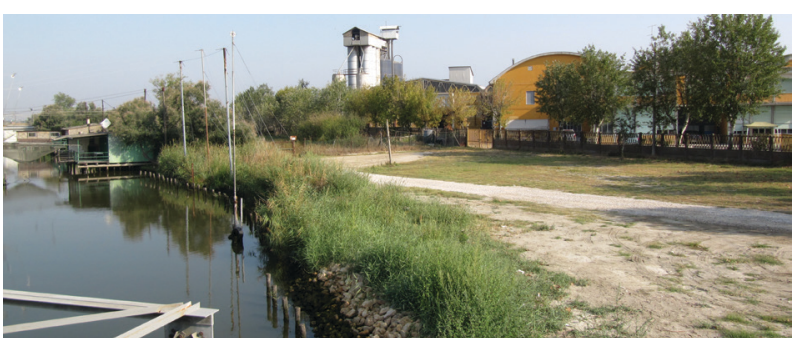

Canal navegável e margens do complexo industrial

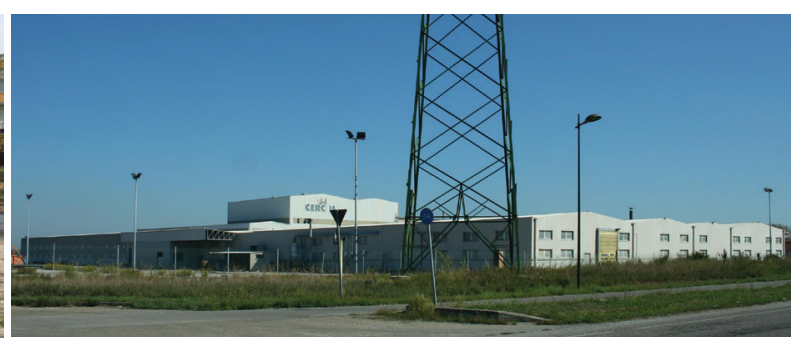

Indústrias Cercom

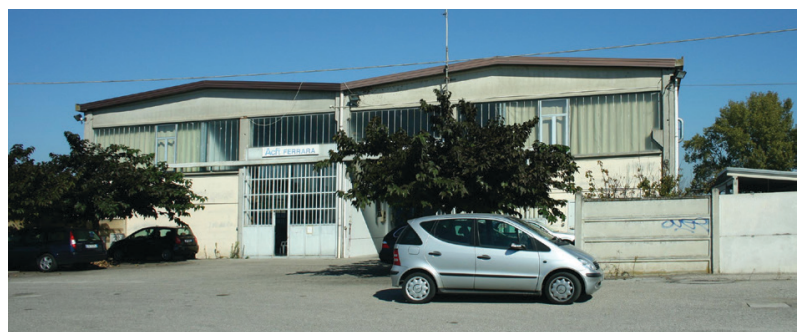

Atividades artesanais atuais

\section{Paisagem infra-estrutural}

A Strada Statale n. 309 tornou-se, ao longo dos últimos cinquenta anos, um percurso muito atrativo, não só pelas suas funções mais relacionadas com a viabilidade rodoviária, entre as quais a distribuição de reabastecimento de combustível, mas também pela variedade de atividades lúdicas e comerciais, como é caso de um centro comercial, um cinema multi-sala, uma zona de fast-food, que fizeram nascer, junto à estrada "Romea", "uma cidade de lazer", caracterizada por elementos típicos nestas situações: exploração intensiva das volumetrias concedidas sem investimento de projeto na qualidade arquitectónica dos volumes estereométricos, painéis publicitários berrantes, a presença de grandes parques de estacionamento e o predomínio de espaços rodoviários em relação às zonas ciclo-pedonais.

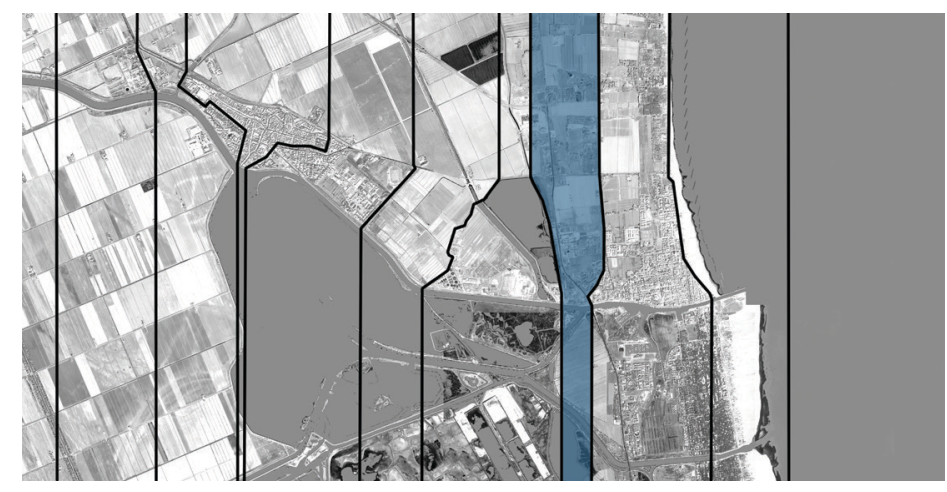




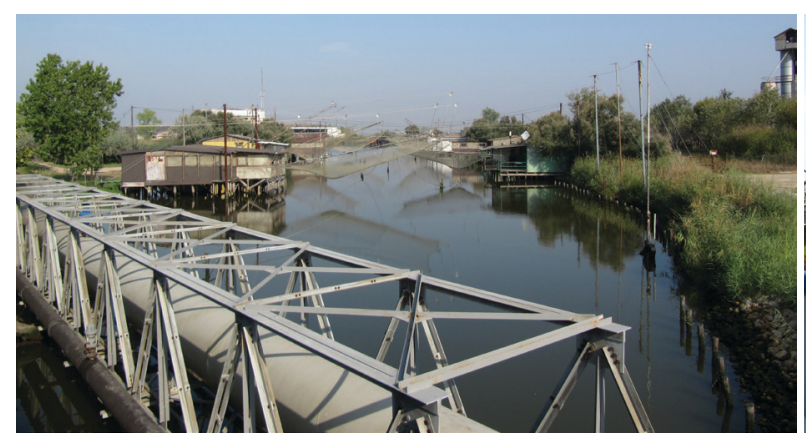

Bilancioni para pesca ao longo do canal navegável

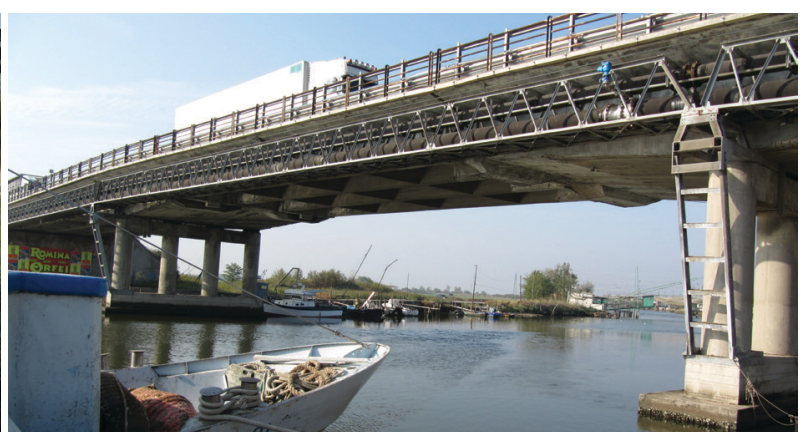

Ponte da estrada SS 309 "Romea"

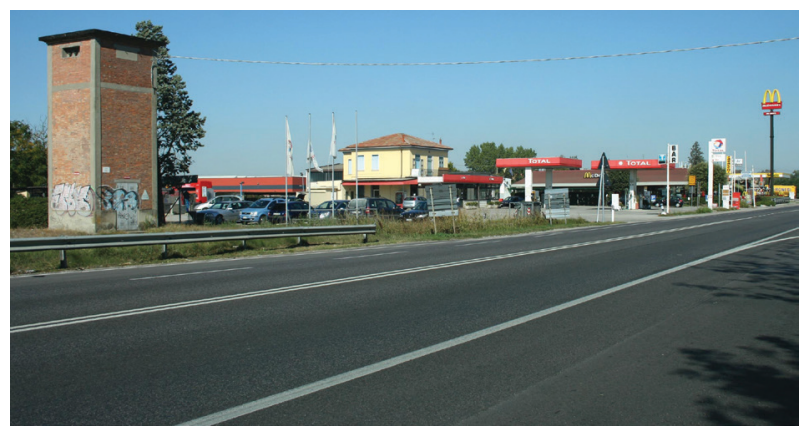

Infraestrutura comercial ao longo da SS 309 "Romea"

\section{Porto costeiro}

Porto Garibaldi é, entre as sete paragens do litoral de Comacchio, o mais urbano, aparecendo como um centro habitacional vocacionado para a pesca, e transformado, no pós-guerra, num complexo turístico. A presença de Porto Canale, com todos os instrumentos ligados à pesca, reforça a peculiaridade do espaço. Ao longo dos últimos vinte anos sucederam-se intervenções de requalificação urbana dos espaços públicos situados na margem do canal, com o intuito de aumentar a atividade turística, também por estar próximo de Lido degli Estensi (ao qual Porto Garibaldi está ligado através de ferry-boat), sede do pólo escolar superior de Comacchio e local muito frequentado, não apenas durante o período estival.

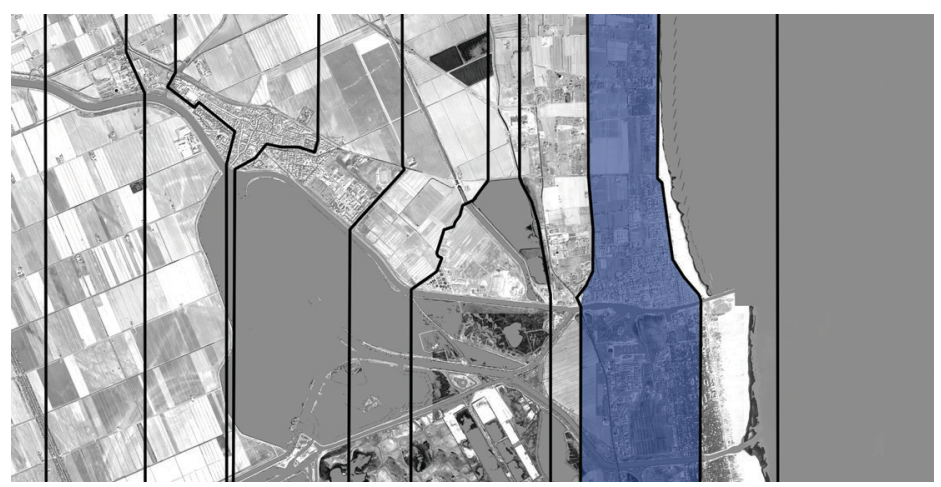




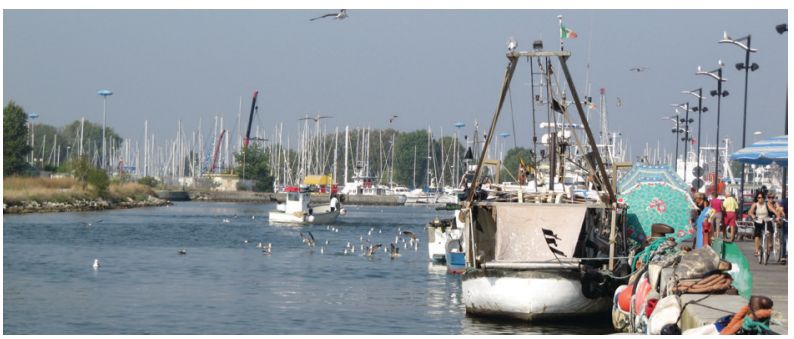

Embarcações ao longo do canal do porto

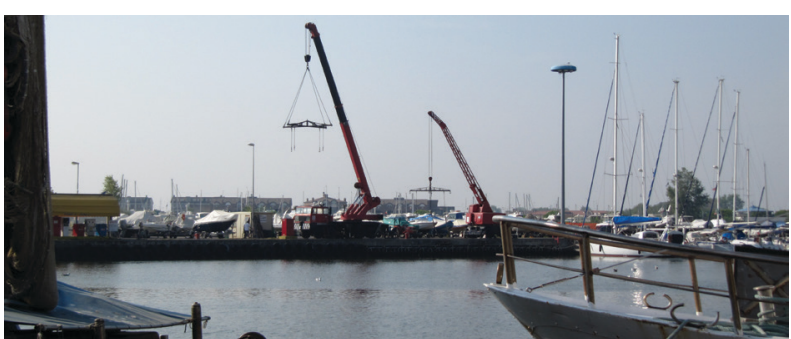

Canal do porto

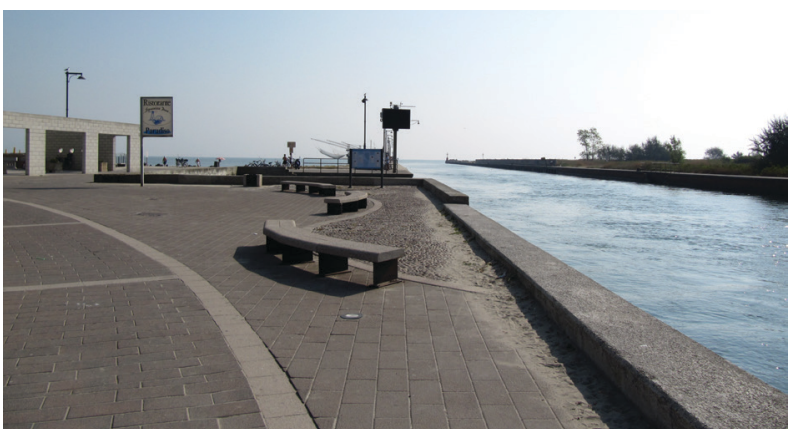

Passeio pedonal ao longo do canal do porto

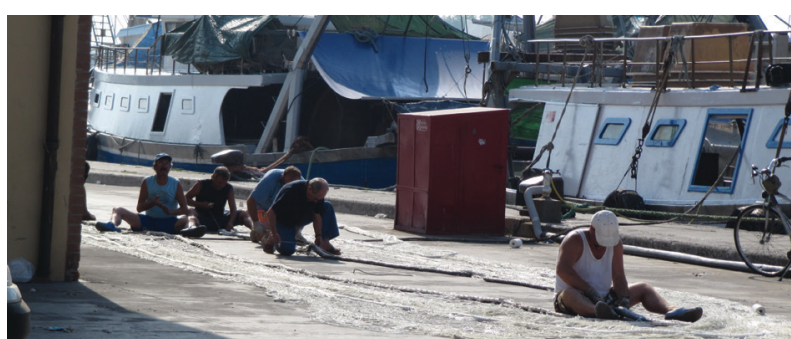

Atividades ligadas à pesca

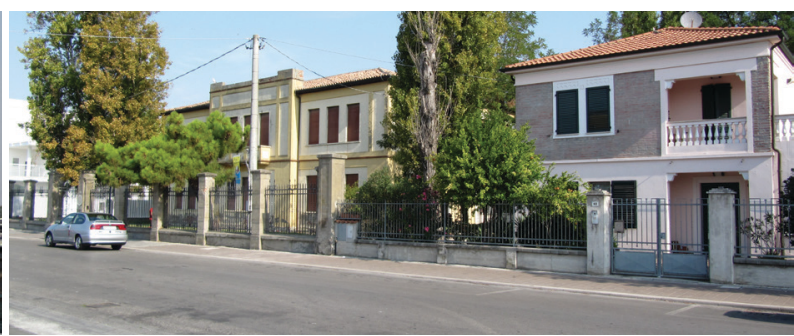

Habitações ao longo do canal do porto

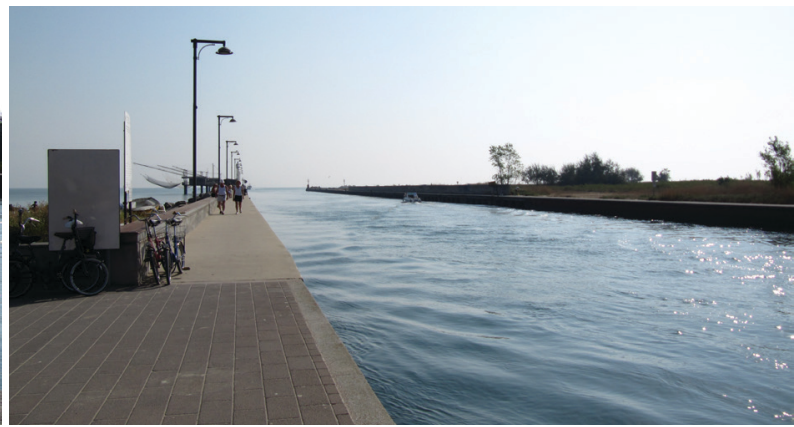

Foz marítima do canal navegável 


\section{Costa}

O troço terminal da via fluvial de Ferrara, situado na margem de Porto Garibaldi, foi, ao longo dos últimos anos, alvo de requalificações urbanas dos espaços públicos, com vista ao aumento da atividade turística, criando um agradável passeio que conduz, e se concluiu, na bandeira marítima do lado norte da entrada no porto. Atualmente, esse troço da via fluvial de Ferrara está a ser alvo de um importante projeto para construir uma saída até ao mar, o que implicará, entre outras coisas, a reestruturação da margem oposta ao canal, na margem de Lido degli Estensi.

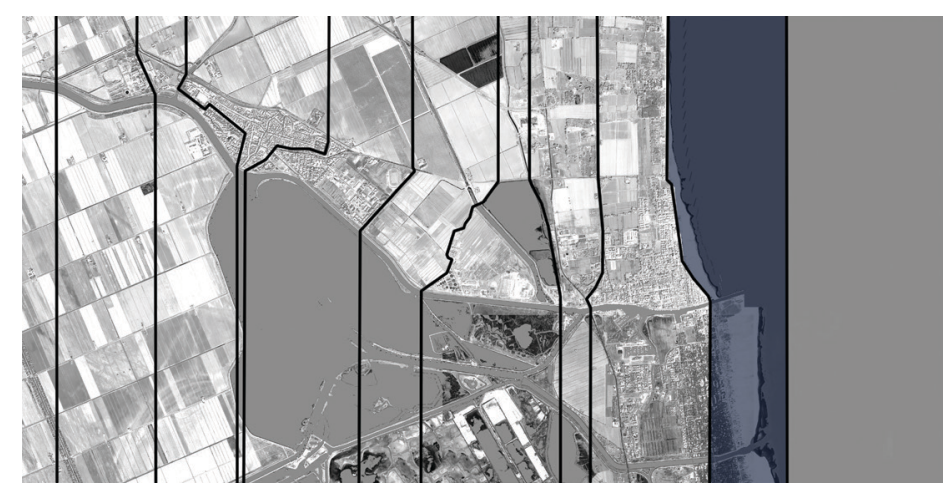

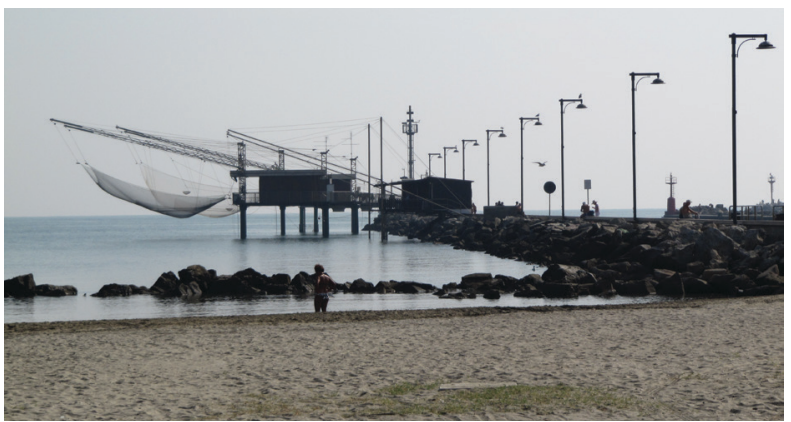

Molhe do canal navegável

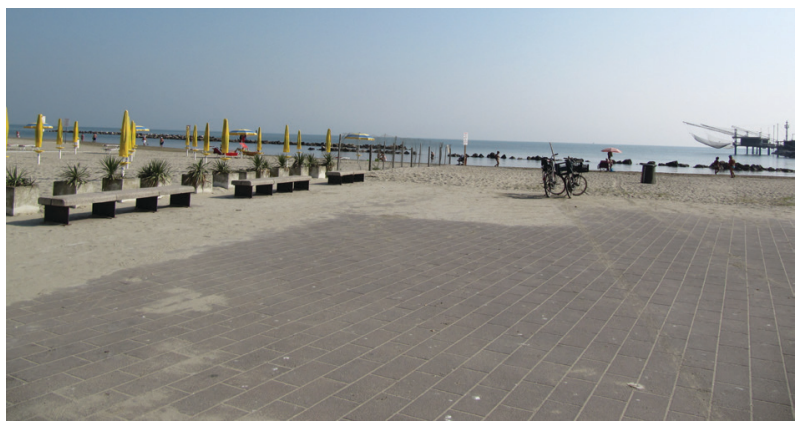

Equipamentos balneares na costa 